\title{
Neurotensin (NTS) and its receptor (NTSR1) causes EGFR, HER2 and HER3 over-expression and their autocrine/paracrine activation in lung tumors, confirming responsiveness to erlotinib
}

\author{
Mohamad Younes ${ }^{1, *}$, Zherui Wu ${ }^{1,2, *}$, Sandra Dupouy ${ }^{1, *}$, Audrey Mansuet Lupo ${ }^{3}$, \\ Najat Mourra ${ }^{1,4}$, Takashi Takahashi ${ }^{5}$, Jean François Fléjou ${ }^{4}$, Jean Trédaniel ${ }^{2,6}$, \\ Jean François Régnard7, Diane Damotte ${ }^{3}$, Marco Alifano ${ }^{2,7}$, Patricia Forgez $^{2}$ \\ ${ }^{1}$ INSERM-UPMC U938, Hôpital Saint-Antoine, Paris, France \\ ${ }^{2}$ INSERM UMR-S 1007, Université Paris Descartes, Paris, France \\ ${ }^{3}$ Pathology Department, Université Paris Descartes, Hôpitaux Universitaires Cochin Hôtel-Dieu Broca, Paris, France \\ ${ }^{4}$ Pathology Department Hôpital Saint-Antoine, Paris, France \\ ${ }^{5}$ Division of Molecular Carcinogenesis, Center for Neurological Diseases and Cancer, Nagoya, Japan \\ ${ }^{6}$ Thoracic Oncology Department, Hôpital Saint-Joseph and Université Paris Descartes, Paris France \\ ${ }^{7}$ Thoracic Surgery Department, Université Paris Descartes, Hôpitaux Universitaires Cochin Hôtel-Dieu Broca, Paris, France \\ *MY, ZW, and SD contributed equally to this work \\ Correspondence to: \\ Patricia Forgez, e-mail: Patricia.forgez@inserm.fr \\ Keywords: Cancer growth and metastasis, neurotensin, EGFR, HER2, HER3, EGF like ligands \\ Received: November 28, $2013 \quad$ Accepted: May 07, 2014 Published: September 27, 2014
}

\section{ABSTRACT}

Alterations in the signaling pathways of epidermal growth factor receptors (HERs) are associated with tumor aggressiveness. Neurotensin (NTS) and its high affinity receptor (NTSR1) are up regulated in $60 \%$ of lung cancers. In a previous clinical study, NTSR1 overexpression was shown to predict a poor prognosis for 5 year overall survival in a selected population of stage I lung adenocarcinomas treated by surgery alone. In a second study, shown here, the frequent and high expression of NTSR1 was correlated with a pejorative prognosis in $\mathbf{3 8 9}$ patients with stage I to III lung adenocarcinoma, and was an independent prognosis marker.

Interactions between NTS and NTSR1 induce pro-oncogenic biological effects associated with neoplastic processes and tumor progression. Here we highlight the cellular mechanisms activated by Neurotensin (NTS) and its high affinity receptor (NTSR1) contributing to lung cancer cell aggressiveness. We show that the NTS autocrine and/or paracrine regulation causes EGFR, HER2, and HER3 over-expression and activation in lung tumor cells. The EGFR and HER3 autocrine activation is mediated by MMP1 activation and EGF "like" ligands (HB-EGF, Neuregulin 1) release. By establishing autocrine and/or paracrine NTS regulation, we show that tumor growth is modulated according to NTS expression, with a low growth rate in those tumors that do not express NTS. Accordingly, xenografted tumors expressing NTS and NTSR1 showed a positive response to erlotinib, whereas tumors void of NTSR1 expression had no detectable response. This is consistent with the presence of a NTS autocrine loop, leading to the sustained activation of EGFR and responsible for cancer aggressiveness.

We propose the use of NTS/NTSR1 tumor expression, as a biomarker for the use of EGFR tyrosine kinase inhibitors in patients lacking EGFR mutation. 


\section{INTRODUCTION}

Lung cancer is the leading cause of cancer-related deaths in western countries [1,2]. Despite advances in medical and surgical care, the 5-year overall survival of NSCLC remains poor (10 to 20\%) [3,4]. The stage of the disease is the most useful parameter in deciding management and defining prognosis. However, survival is heterogeneous even within a single stage $[3,5]$. Therefore, the identification of biological parameters allowing characterization, and validation of tumor subsets possessing aggressive phenotypes, is an ongoing challenge for lung cancer biological studies. In recent years, significant progress has been made in understanding the molecular mechanisms of bronchial carcinogenesis. For example, recent success in new cancer therapies targeting epidermal growth factor receptors, or their downstream signalization, illustrated their decisive roles in tumor aggressiveness [6,7]. Malignant transformation of normal bronchial cells is a multistep process, characterized by the accumulation of sequential genetic or epigenetic alterations [8]. Some of these genetic alterations such as EGFR mutations, and ALK gene rearrangements offer opportunities to identify and characterize subpopulations of patients eligible for specific therapies $[9,11]$.

In tumoral cells, EGFR, HER2, HER3, and HER4 functions can be abnormally exacerbated because of genetic defaults, protein over-expression, or overactivation of one or several of these receptors. In tumors, these regulations are not mutually exclusive and confer a large magnitude of oncogenic activities. Constitutive activation of HERs induces sustained proliferative signaling, and activates invasion and metastasis, both hallmarks of cancer [8]. Constitutive activation of HERs becomes installed with the overexpression of matrix metalloproteinases (MMPs) and the subsequent activation of EGF "like" ligands. Activation of the matrix metalloproteinases, MMPS and ADAMS, provokes the shedding of EGF "like" ligands [12], with autocrine or juxtacrine activation of EGFR and HER3, occurring with the shedding of HB-EGF, a specific ligand for EGFR, and neuregulin a specific ligand for HER3 [13]. Whereas, it is clear that this participates in the aggressive phenotype of the tumoral cells, it is difficult to target this cascade with therapeutic molecules because it encompasses many factors and effectors. Finding an upstream factor which could be pharmacologically targeted would be a more successful strategy.

NTS, a 13 amino acids peptide, is present and biologically active in the central nervous system and in periphery $[14,15]$. At the peripheral level, neurotensin is released by the endocrine cells $(\mathrm{N})$ of the intestinal mucosa after meals and acts as an endocrine hormone involved in the postprandial regulation of the motor functions of the gastrointestinal tract [16]. The effects of NTS are mediated by three subtypes of receptor; NTSR1 and NTSR2 exhibit high (sub-nanomolar) and low (nanomolar) affinity for NTS, respectively, and belong to the family of G protein receptors. NTSR3 or gp/95/sortilin is a single transmembrane domain receptor [17].

Exogenous activation of NTSR1 leads to cell proliferation, survival, mobility and invasion in cancer cells from diverse origin $[18,19]$. These effects are the result from the activation of kinases and effectors, such as PKC, MAPK, FAK, RHO-GTPase, RAS and Scr $[20,25]$. The PKC activation may induce MAPK by direct stimulation of Raf-1, or by transactivation of the Epidermal Growth Factor Receptor (EGFR) [20,26,27]. The activation of MAPK via NTSR1 is mainly associated with uncontrolled cell growth, which aggravates the growth of tumors [28,29].

We have focused on the contribution of NTS/ NTSR 1 complex in breast and lung cancers. In breast cancer cells, NTSR1 up regulation was the result of beta catenin cellular and nuclear delocalization [30]. Both NTS and NTSR 1 were expressed in 20 and $40 \%$ of the tumor breast and lung tumors, respectively. NTSR1 high expression is a negative prognostic marker in a selected population of stage I lung adenocarcinomas, treated by surgery alone, and in ductal invasive carcinomas [31,32]. The removal of NTSR1 expression in both lung and breast cancer cells caused a reduction of tumor growth and metastasis, demonstrating the contribution of this complex in tumor progression in breast and lung cancers $[31,33]$. NTSR 1 is a G protein coupled receptor endocytosed following NTS exposure. We have shown that intense and chronic NTS exposure lead to the sustained activation of NTSR 1 signaling and NTS targeted genes $[34,36]$. These cellular conditions are similar to autocrine and paracrine exposition that would occur in human tumor cells since both factors are expressed in human cancers.

In this study, we highlight the contribution of autocrine and paracrine NTS regulation to lung cancer cell aggressiveness. We show that sustained stimulation of NTSR1 results in the activation of MMP1, the release of HB-EGF and NGR1 followed by EGFR, HER2 and HER3 overexpression and activation. This cascade results in an increase in the growth of experimental lung tumors.

\section{RESULTS}

\section{The NTS/NTSR1 complex enhances cellular growth}

In previous studies, we showed that both NTS and NSTR1 are concomitantly expressed in human lung tumors. NTS actions, possibly occurring in tumor, are therefore mediated through autocrine and/or paracrine regulation [31]. In order to evaluate the contribution 
of NTS in the context of autocrine and/or paracrine regulation, we studied cellular subpopulations from the highly metastatic lung carcinoma cell line, LNM-35 [37]. LNM-R cells (expressing NTS and NTSR1) and LNM-F cells (expressing mainly NTSR1) were isolated from the parental LNM-35 cells and the observed phenotypes remained with cultured passages (Figure 1A inset).

We confirmed the differential expression of NTS in the two subclones by radioimmunoassay. The LNM-R culture media contained large amounts of NTS, which accumulated with time (75 to $625 \mathrm{fmol} / \mathrm{ml}$ ), whereas the media of LNM-F cells contained 20 fold less NTS (Figure 1S A). NTSR1 immunocytochemistry experiments revealed a non-activated NTS/NTSR1 state in LNM-F cells, with NTSR1 localization at the cell surface. In contrast, a constitutively activated state of NTSR 1 was found in LNM-R cells as revealed by the localization of NTSR1 in a peri-nuclear area (Figure 1S B) [36].

We first evaluated the contribution of NTS/NTSR1 complex on cellular growth on the LMN-R cells silenced for NTS or NTSR1. The clones were named R-SI NTS and R-SI NTSR1, respectively [31] (Figure 1A inset). Exogenous chronic treatment (48h) of R-SI NTS cells with NTS or a low degradable NTS agonist, JMV 449, induced a two fold increase in the cellular growth (Figure 1 A). In contrast, R-SI NTSR1 cells were not responsive, as expected, since the NTSR1 was silenced.

To analyze the autocrine/paracrine cooperativity of the NTS/NTSR1 complex, we created an in vitro model, by mixing LNM-F and LNM-R cell subpopulations. Cells were seeded at sub-confluency with a ratio of $20 \%$ of LNM-R and $80 \%$ of LNM-F, (R/F 20/80), and counted after $72 \mathrm{~h}$ of culture. This proportion of the cell subpopulations was chosen because it is similar to the proportion of LNM-R and LNM-F cells in the parental cell line, LNM-35. We observed an increase of $60 \%$ in the number of cells of the mix R/F 20/80 compared to LNM-F or LNM-R culture alone (Figure 1B). Fluorescence activated cell sorting showed a higher proportion of cells in $\mathrm{S}$ phase and a smaller proportion in G1 phase, as compared to LNM-F cells cultured alone (Figure 1S C). To confirm the implication of NTSR1 in the observed growth induction in $\mathrm{R} / \mathrm{F} 20 / 80$, cells were exposed to BIM 46174 [38], an inhibitor of heterotrimeric G proteins, SR 48692 [39], a specific NTSR1 antagonist, and NTS neutralizing antibody. These compounds abolished the increase of tumor growth observed in the cell mixture R/F 20/80 (Figure 1C). A contribution of epidermal growth factor receptors (HERs) to induce NTS cellular growth was suggested by the abolishing effect of M475271, a Src kinase inhibitor, AG 1478, a specific inhibitor of EGFR, and herceptin (trastuzumab), an antibody specific to HER2, which abrogate the growth enhancement effect (Figure 1D). Chemical inhibitors confirmed the contribution of NTSR1 and HERs downstream pathways. Cellular growth amplification was abolished by a PKC inhibitor, Gö 6976, (Figure 1E), whereas the NO inhibitor, L-NAME, and the PKA inhibitors, H7, had no effect (Figure 1F). The effect was also abolished by MEK Inhibitors, U0126 and PD98059, and the phosphoinositide 3-kinases inhibitor, the LY294002 (Figure 1E).

\section{The NTS/NTSR1 complex enhances EGFR, HER2 and HER3 expression and activation}

The previous results highlighted a specific effect of NTS in oncogenic processes occurring through an interrelation between NTS/NTSR1 and receptor tyrosine kinase systems. We therefore measured the HERs cellular protein content in the mixture of R/F 20/80 cells cultured as previously described. An increase of HER2 and HER3 protein levels, and to a minor extent, EGFR protein levels was observed (Figure 2A). This effect was abolished by SR 48692 as shown on gel figure 2B. Surprisingly, similar mRNA levels were seen for the three receptors in LNM-R/LNM-F 20/80 as well as LNM-R and LNM-F cultured alone (Figure $2 \mathrm{~S}$ ). The accumulation of the HERs protein without transcriptional regulation suggests that the recycling and degradation of these receptors is altered by NTS/NTSR1 interaction. This is in line with our previous findings showing that sustained NTSR1 activation installs a state of permanent recycling of NTSR1, instead of agonist induced lysosomal degradation [36].

Western blot analysis of R-SI NTS cells exposed for $48 \mathrm{~h}$ to exogenous NTS agonist also showed a marked increase of HER2 and HER3 protein content. These increases were totally abolished by SR 48692 treatment (Figure $2 \mathrm{C}$ and inset). No obvious changes was observed, by immunocytochemistry, in EGFR labeling in R-SI NTS cells, treated or not with JMV 449. In contrast, HER2 and HER3 staining were more intense at the membrane and in the cytosol of cell exposed to NTS agonist (Figure 2D). In both experiments, continued exposition to NTS in cells expressing NTSR1 induced the remodeling of HER2 and HER3 expression associated with more aggressive phenotype.

To explore if these mechanisms occur in human tumoral cells, we searched the consecutive slides from 27 specimens with lung adenocarcinoma for clusters of cells concomitantly labeled for NTS, NSTR1, HER2 and HER3. Concomitant expression was observed in restrictive areas of 19 specimens, and examples are shown in figure 2E. However, in 8 other specimens' concomitant overexpression could not be observed. These observations suggest the up regulation of HER2 and HER3 by NTS is specific of lung tumoral cells. 

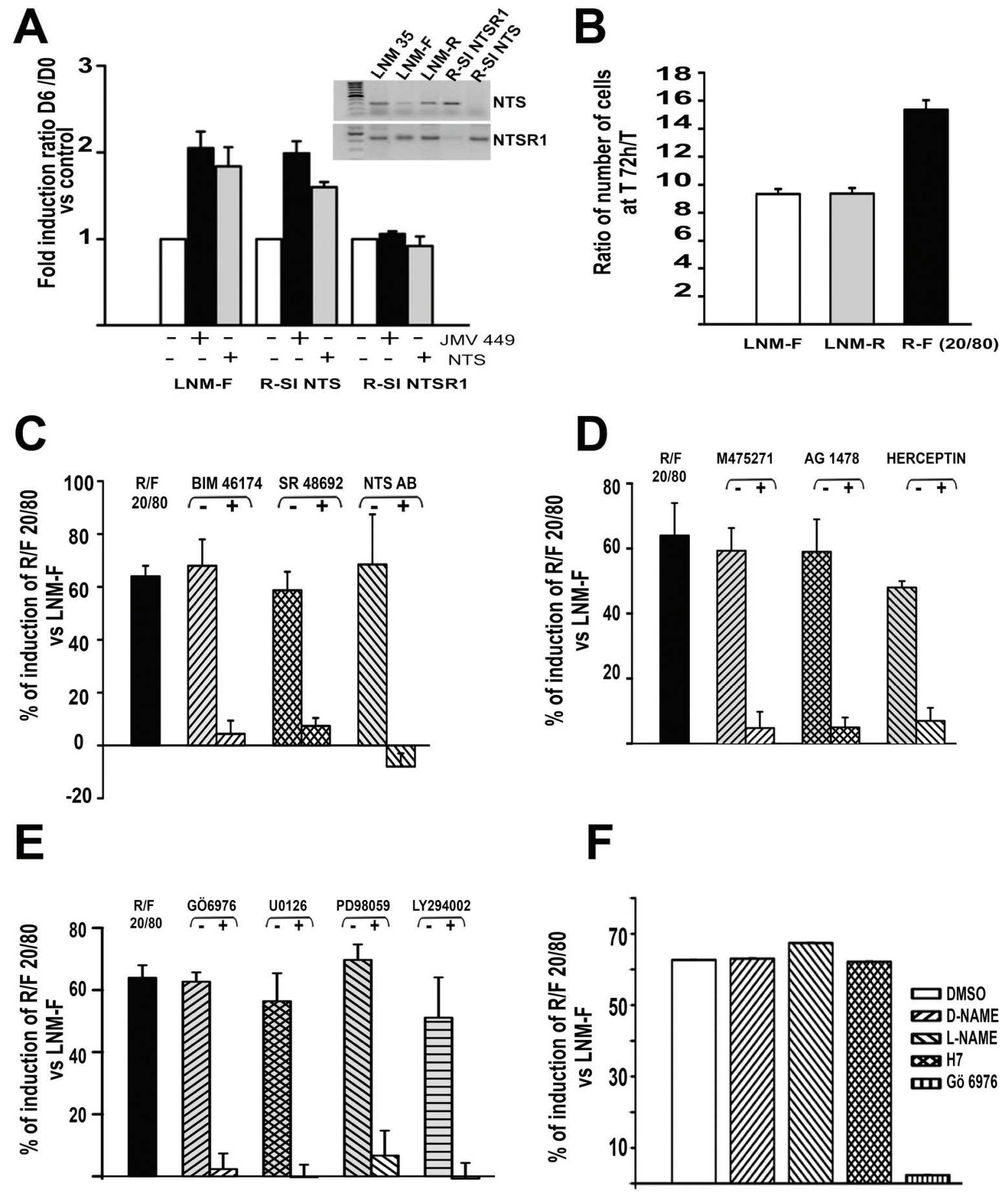

Figure 1: NTS autocrine and paracrine regulation enhanced cellular growth in human lung cancer cell lines. (A) Influence of NTS exogenous treatment on lung cancer cell growth. LNM-F, R-SI NTS and R-SI NTSR1 were grown in media containing $0 \%$ FCS at low concentration and treated every day with $10^{-8}$ M NTS or JMV 449 for 6 days. The ratio of the number of cells at Day 6/Day 0 was calculated. The result is expressed as the \% of fold induction. Inset, NTS and NTSR1 transcripts analysis from a total of $200 \mathrm{ng}$ of LNM-35, LNM-R, LNM-F, R-SI NTSR1 and R-SI NTS total RNA. (B) LNM-R and LNM-F were seeded alone or at the ratio of 20/80 LNM-R/LNM-F and grown in $0.1 \%$ FCS for $72 \mathrm{~h}$. The results are expressed as the ratio of the number of cells at $72 \mathrm{~h}$ to $\mathrm{T} 0$ was calculated, and are the mean \pm SEM of 7 independent experiments. C to F) LNM-R and LNM-F were seeded alone or at the ratio of 20/80 LNM-R/ LNM-F and grown in $0.1 \%$ FCS for $72 \mathrm{~h}$, The ratio of the number of cells at $72 \mathrm{~h}$ to T0 was calculated. The results are expressed as the percentage of the growth induction compared to LNM-F. Results are the mean \pm SEM of 2 to 5 independent experiments. Cells were

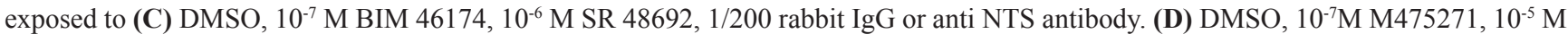
AG1478, PBS, or $50 \mu \mathrm{g} / \mathrm{ml}$ Herceptin. (E) $5 \times 10^{-6} \mathrm{M}$ Gö6976, $10^{-6} \mathrm{M}$ U0126, $10^{-6} \mathrm{M}$ PD98059, or $10^{-7} \mathrm{M}$ LY294002. F) DMSO, $10^{-5} \mathrm{M}$ D-NAME, $10^{-5} \mathrm{M}$ L-NAME, $10^{-5} \mathrm{M} \mathrm{H7}$ or $510^{-6} \mathrm{M}$ Gö6976. 
A

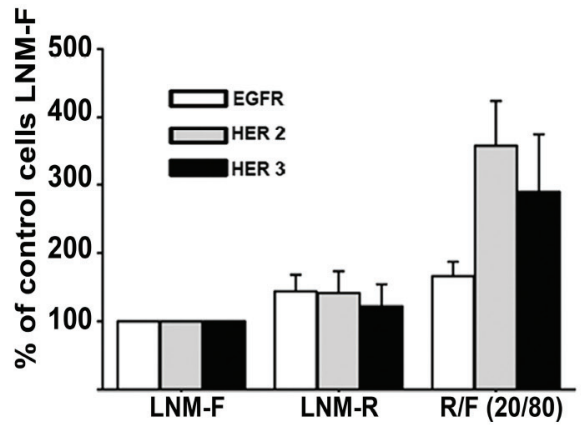

C

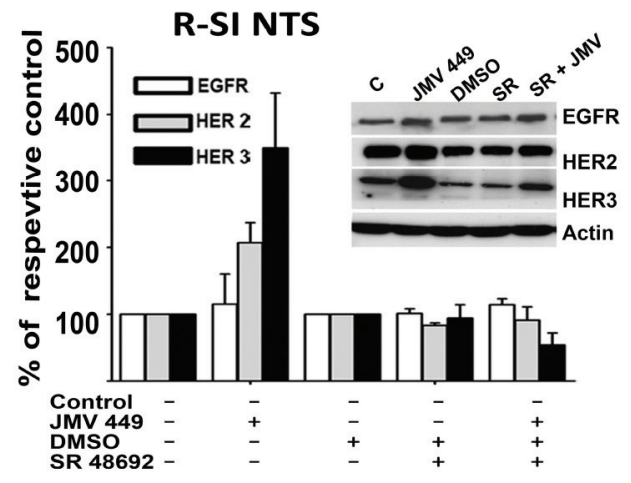

B
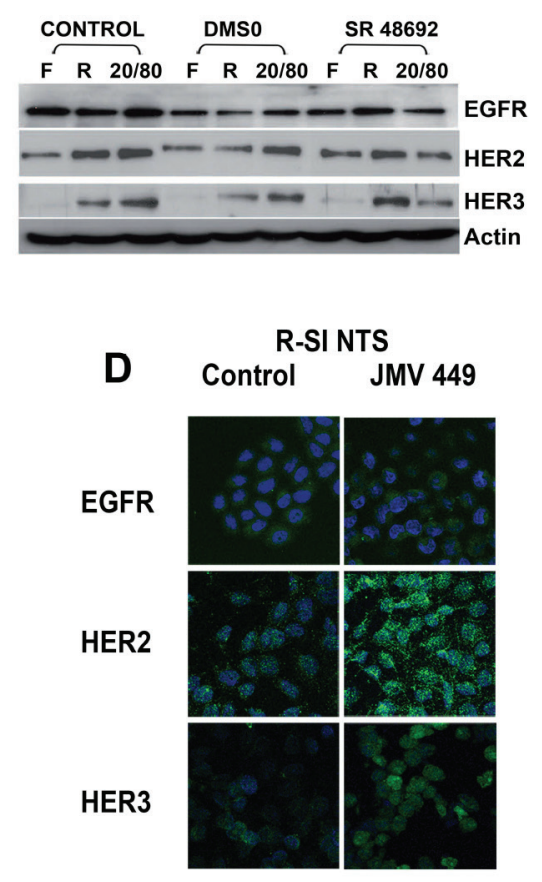

E

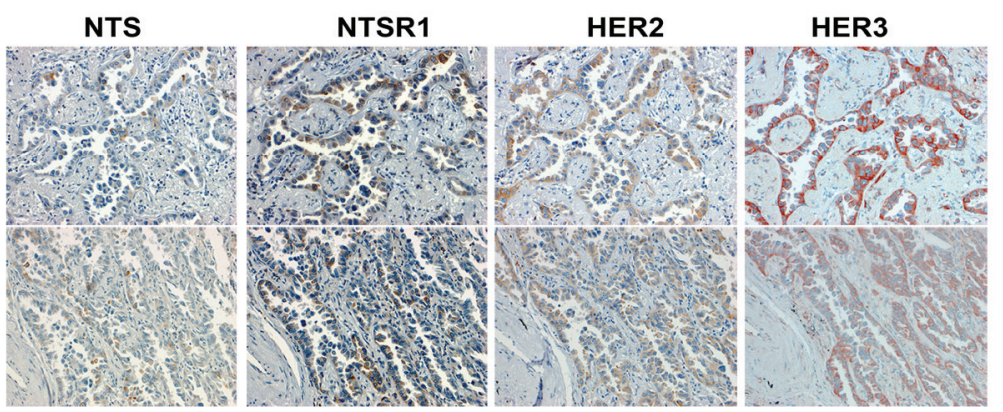

Figure 2: NTS regulation enhanced HER2, and HER3 basal expression in human lung cancer cell lines. (A) The mixture of cells R/F 20/80 lung cancer cells cultured for 72h, with the histograms representing intensity-based quantification of Western blot bands of basal total protein, EGFR, HER2, and HER3, Values are expressed as the percentage of the control LNM-F cells (which are the population more representative of the mixture) and are the mean \pm SEM of 5 to 8 independent experiments. (B) An example of western blot gel of LNM-F, LNM-R and the mixture LNM-F, LNM-R (20/80) cultured for $72 \mathrm{~h}$ no treated or treated with DMSO or $5 \times 10^{-6}$ M SR 48692 . The blots were revealed with EGFR, HER2 or HER3 antibodies. The actin shown is to the protein control for the HER3 Blot (C) Lung cancer cells R-SI NTS treated or not with $10^{-7} \mathrm{M}$ JMV 449, DMSO or $5 \times 10^{-6} \mathrm{M}$ SR 48692 for $48 \mathrm{~h}$. The histograms represent intensitybased quantification of Western blot bands of basal total protein, EGFR, HER2, and HER3. Values are expressed as the percentage of the non-treated cells (control), and are the mean \pm SEM of 3 to 6 independent experiments. . Inset, An example of western blot gel of R-SI

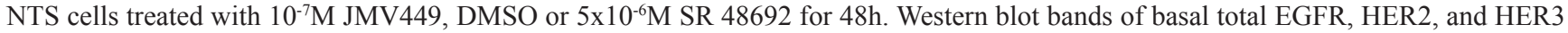
protein. (D) EGFR, HER2, and HER3 immunolabeling in R-SI NTS cells treated of not with $10^{-7} \mathrm{M} \mathrm{JMV} 449$ for $48 \mathrm{~h}$. (E) Example of two restrictive areas from a patient with lung adenocarcinoma with a positives labeling for NTS, NTSR1, HER2, HER3.

\section{NTS induced EGFR, HER2 and HER3 activation mediated by MMPs activation and EFG "like" ligand release}

In parallel, we observed a sustained activation states for all three receptors. R-SI NTS cells treated by JMV449 for 48 h, showed an increase of $250 \%$ for the three receptors. This enhancement was completely abolished with treatment by SR 48692 and a metalloproteinase inhibitor, iMMP (Figure 3A and B). Metalloproteinases are known, through proteolysis process, to establish HERs autocrine activation with the shedding or activation of EGF "like" ligand at the cell membrane. We searched for an activation of EGF "like" ligands by NTS. We found a major increase in HB-EGF levels in R-SI NTS cells media treated with NTS agonist for $24 \mathrm{~h}$, and a decrease of HBEGF cellular production when LNM-R were exposed to SR 48692 (Figure 4A). In this cell, EGFR autocrine regulation 

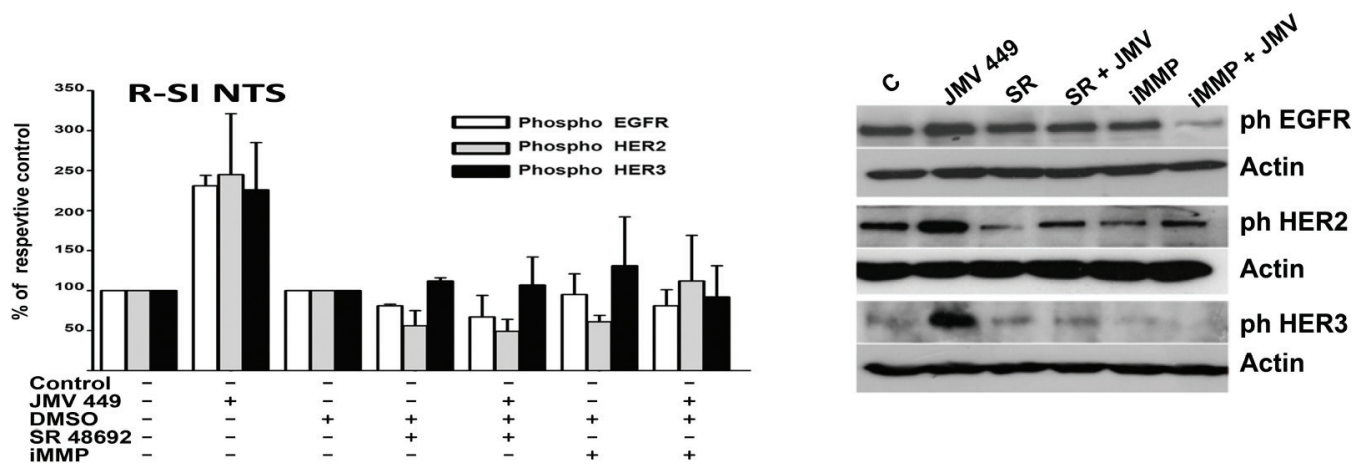

Figure 3: NTS regulation enhanced EGFR HER2, and HER3 activation in human lung cancer cell lines. (A) Lung cancer cells R-SI NTS treated or not with $10^{-7} \mathrm{M}$ JMV 449, DMSO, $5 \times 10^{-6} \mathrm{M}$ SR 48692 or $2510^{-9} \mathrm{M}$ iMMP for $48 \mathrm{~h}$. The histograms representing intensity-based quantification of Western blot bands of phosphorylated protein, EGFR, HER2, and HER3. Values are expressed as the percentage of the non-treated cells (control), and are the mean \pm SEM of 3 to 4 independent experiments. (B) An example of a western blot gel of R-SI NTS cells treated with $10^{-7} \mathrm{M}$ JMV449, DMSO, $5 \times 10^{-6} \mathrm{M}$ SR 4869 or $25 \times 10^{-9} \mathrm{M}$ iMMP for $48 \mathrm{~h}$. Western blots bands of phosphorylated EGFR, HER2, and HER3 protein.

by HB-EGF would be enhanced by the release of HB-EGF under the influence of NTS. Similarly, neuregulin 1 (NRG1), a specific ligand for HER3, was found more intensively released when R-SI NTS cells were treated with NTS agonist. In LNM-R cells, the NTSR1 antagonist, SR48692 reduced the amount of NRG1 released in the culture media. Increased amounts of activated NRG1 sustained the hypothesis of HER3 autocrine regulation established under NTS exposure (figure 4B). In parallel, MMP1 was found to be released in the media of R-SI NTS cells treated with NTS agonist (Figure 4C). In cells bearing NTS autocrine regulation, MMP1 released was also decreased in the presence of SR 48692 (Figure 4C). Several matrix metalloproteases are regulated in NSCLC including MMP1, which is up regulated in both adenocarcinomas and squamous cell lung cancer [40].

\section{NTSR1 activation in experimental tumors}

In order to apprehend the contribution of NTSR1 in lung tumorigenesis, we developed experimental tumors bearing NTS autocrine, and/or paracrine, or endocrine regulation. We established the growth rate of LNM35 tumor xenografts in the nude mice, in comparison with the two derived sub-clones, LNM-R (NTS+) and LNM-F (NTS-). As shown in figure 5A, LNM35 xenografts displayed the more drastic tumorigenesis profile with a final tumor volume of $4122 \mathrm{~mm}^{3}$. The sub-clones LNM-R, and LNM-F generated smaller tumors with a final volume of 2582 and $1858 \mathrm{~mm}^{3}$, respectively. The tumor size is 38 and 55\% smaller than LNM35 when generated by LNM-R and LMN-F, respectively. The difference in the tumor growth rates between the parental cells and the two subclones suggests a positive cooperativity between these two cellular populations. To confirm this hypothesis, we mixed the two subclones at the same density before injecting into the mice. The same rate of tumor growth was then observed by injecting LNM35 cells $\left(4122 \mathrm{~mm}^{3}\right)$ or the LNM-F and LNM-R mixture $\left(3782 \mathrm{~mm}^{3}\right)$, as shown in figure $5 \mathrm{~A}$. The tumor weight observed at 28 days postinjection followed the same variation as the tumor volume (Figure 3S A). NTS and NTSR1 immunohistochemistry was performed on tumors. The presence of NTSR1 was seen in both LNM-R and LNM-F tumors (Figure 5B), but with a granular and irregular intensity of labeling. In order to better visualize NTS, we used an antibody against a NTS precursor, which detected the presence of NTS precursor in LMN-R and its absence in LNM-F tumors (Figure 5B).

We explored the effects of NTS systemic regulation on the tumor growth enhancement. R-SI NTS cells were injected subcutaneously into the right flank and R-SI NTSR1 cells in the left flank of the mice. Figure 5C shows that the R-SI NTS tumor xenografts reach the size and weight (Figure 3SB) of the tumors initiated by the corresponding LMN-R parental cells, whereas R-SI NTSR1 tumors remain at the same smaller size that was observed in mice bearing only R-SI NTSR 1 xenografts, suggesting that the circulating NTS produced by the R-SI NTSR1 tumor enhanced the tumor growth of R-SI NTS xenografted into the other flank.

We evaluated the relative tumorigenic potential of the NTS autocrine and/or paracrine regulation. R-SINTS and LNM-R cells were mixed to generate xenografts bearing autocrine and paracrine NTS regulation as expressed in the original parental cells LNM35 and in the mixture LNM-R and LNM-F. Alternatively, we mixed cell lines not expressing NTS (R-SI NTS and LNM-F cells). When R-SI NTS and LNM-R cells mixture was injected in mice, the size of the tumor generated by this heterologous cell population $\left(4122 \mathrm{~mm}^{3}\right)$ was similar to tumors generated by the parental LNM35 cells $\left(3885 \mathrm{~mm}^{3}\right)$, and the mixture of LNM-R and LNM-F $\left(3782 \mathrm{~mm}^{3}\right)$ 
A

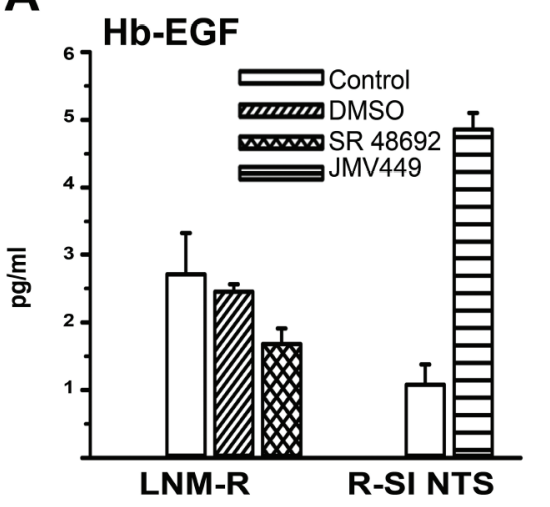

B

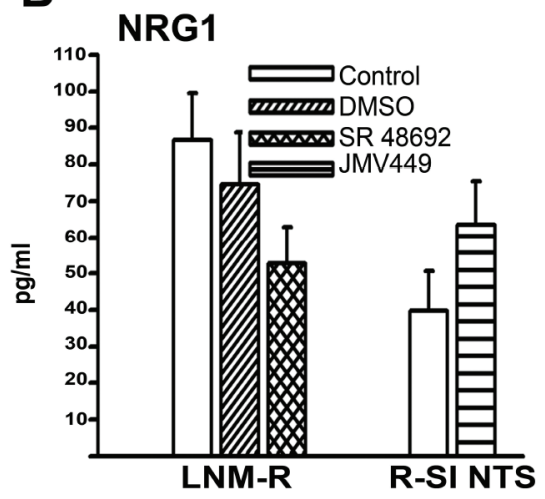

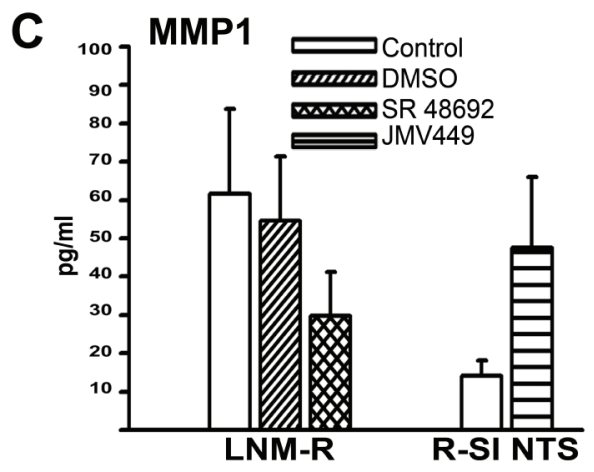

Figure 4: NTS autocrine and paracrine regulation activate EGF "like" ligands and MMP1 in lung cancer cell lines. (A) Amount of Hb-EGF (pg/ml), assayed in $0 \%$ FCS culture media of LNM-R cells not treated, or treated for $48 \mathrm{~h}$ with DMSO, $5 \times 10^{-6} \mathrm{M}$, SR 48692. R-SI NTS cells were treated or not for $24 \mathrm{~h}$ with $10^{-8} \mathrm{M} \mathrm{JMV} 449$. Using Paired $\mathrm{t}$ test $\mathrm{p}=0.065$ between DMSO and SR 48692 in LNM-R treated cells $\mathrm{n}=3 ; \mathrm{p}=0.0015$ between control and JMV 449 R-SI NTS treated cells $\mathrm{n}=3$. (B) Amount of NRG1 ( $\mathrm{pg} / \mathrm{ml}$ ) assay in $0 \%$ FCS culture media of LNM-R cells not treated or treated for $48 \mathrm{~h}$ with DMSO, $5 \times 10^{-6} \mathrm{M}$ SR 48692 , or in R-SI NTS cells treated for $48 \mathrm{~h}$ with $10^{-8} \mathrm{M}$ JMV449. Paired $t$ test $p=0.04$ between DMSO treated and SR 48692 LNM-R treated cells $n=8 ; p=0.001$ between control and JMV 449 R-SI NTS treated cells, $\mathrm{n}=7$. (C) Amount of MMP1 (pg/ml) assay in $0 \% \mathrm{FCS}$ culture media of LNM-R cells not treated or treated for $48 \mathrm{~h}$ with DMSO, $5 \times 10^{-6} \mathrm{M}$ SR 48692, or in R-SI NTS cells treated for $48 \mathrm{~h}$ with $10^{-8} \mathrm{M}$ JMV449. Using Paired $\mathrm{t}$ test $\mathrm{p}=0.03$ between DMSO and SR 48692 LNM-R treated cells, $\mathrm{n}=4$; $\mathrm{p}=0.036$ between control and JMV 449 R-SI NTS treated cells, $\mathrm{n}=7$.

(Figure 5D) demonstrating that in all cases, the NTS autocrine regulation participates with paracrine regulation to strongly enhance tumor progression. In contrast, when a mixture of the R-SI NTS and LNM-F cells, not expressing NTS, was xenografted in nude mice, the tumor volume was globally $40 \%$ smaller than the xenografts bearing NTS autocrine and paracrine regulation (Figure 5D). Identical observations were made for the tumor weight (Figure 3S C). When the cells do not release NTS, there is no cooperation between cells, and tumor growth is slower. The overall conclusion of this series of experiments suggests that NTS participates in enhancing tumor growth via autocrine, paracrine and systemic pathways.

\section{Tumors expressing NTS/NTSR1 are responsive to EGFR inhibitors}

We evaluated the therapeutic effects erlotinib, and metformin, on cells expressing both NTS and NTSR1 and cells none expressing NTSR1. Erlotinib is an EGFR specific tyrosine inhibitors currently proposed to patients with advanced NSCLC patients harboring EGFRactivating mutations [41]. Metformin is an antidiabetic drug, and has recently been proposed as a potential anticancer compound [42]. Metformin was shown to disrupt the crosstalk between insulin receptor and NTS receptor in pancreatic cancer cells [43]. Furthermore, in addition to inhibiting the mTOR pathway, metformin prevents ERK activation induced by NTS and insulin [44].

Mice were xenografted with LNM-R cells expressing NTS and NTSR1 on the right side and with a derived clone R-SI NTSR1 [31], deleted for NTSR1 expression with a stable expression of sh-NSTR1 plasmid on the left side (Fig 6A). The LNM-R cells did not carry the following activating EGFR mutations: exon 19 deletion, exon 20 insertion, or exon 18 Q719A, Q719C, Q719S and exon 21 L858R, L861Q point mutations. As these cells are very aggressive, with a very high growth rate, we randomized the mice when the volumes of LNM-R tumors reached approximately $20 \mathrm{~mm}^{3}$. LNM-R tumors were sensitive to erlotinib and to a lesser extent to metformin. The final tumor volume after 17 days 
A
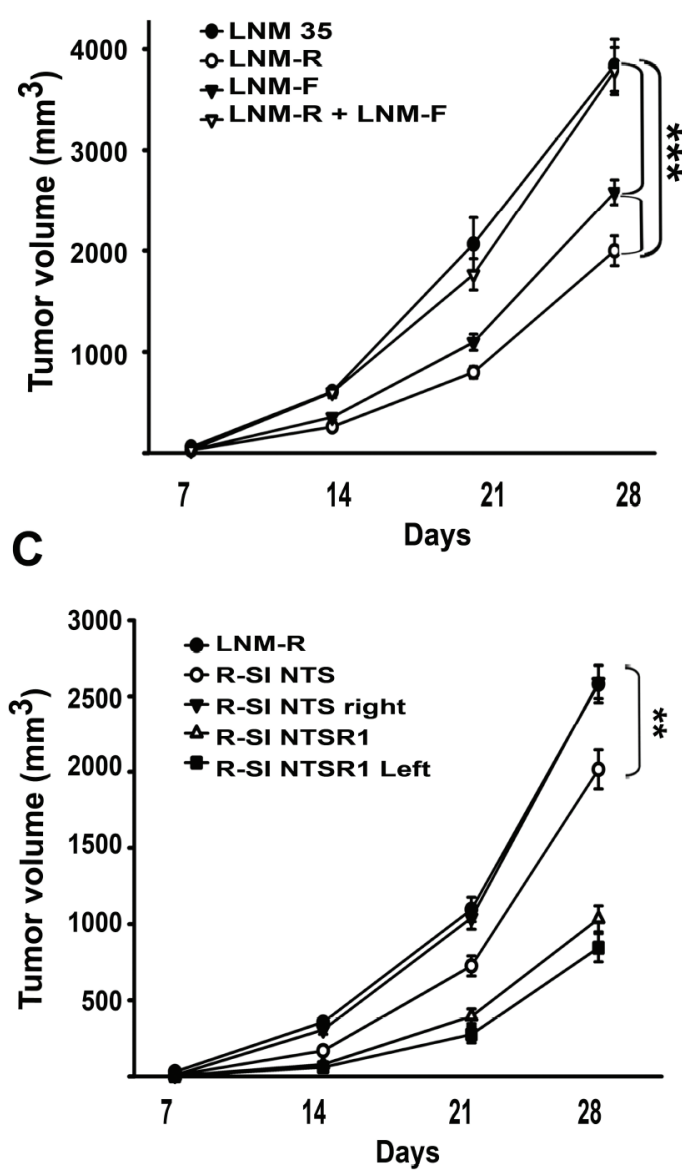

B

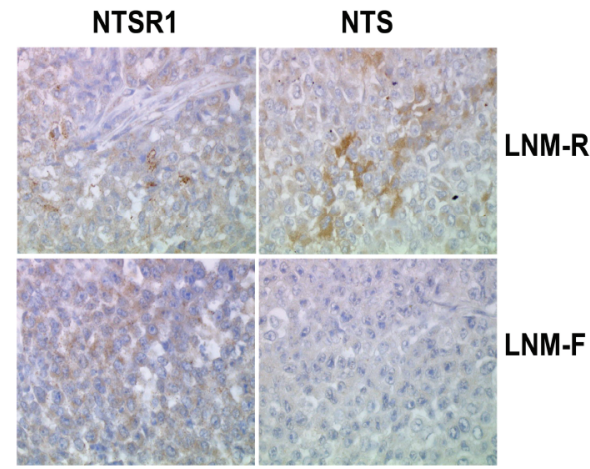

D

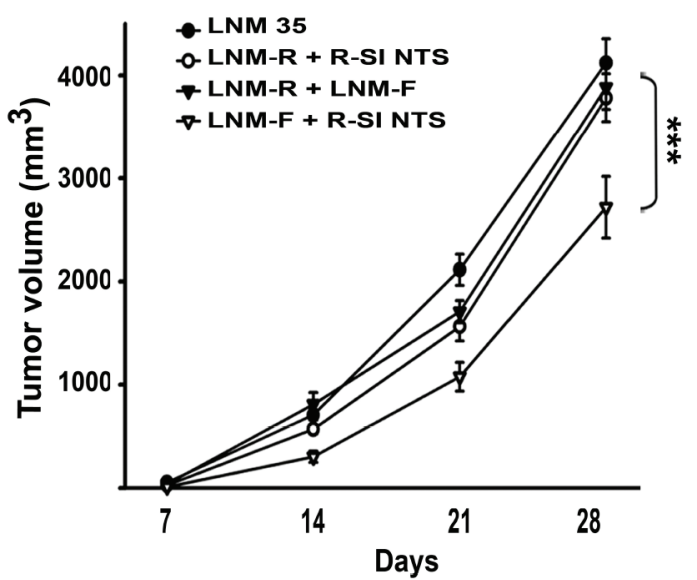

Figure 5: NTS/NTSR1 complex enhanced experimental tumor growth. (A) Tumor growth generated by LNM35, LNM-R and LMN-F cells xenografted into nude mice. One million cells from LNM35, LNM-R, LNM-F, or a mixture of LNM-R and LNM-F (50/50) were subcutaneously injected in 24, 36, 34, or 12 nude mice, respectively. (B) Typical immunohistochemistry for NTSR1 (left) or NTS (right) for tumors generated from LNM-R (top) or LNM-F (bottom) cells. Significant differences at *** $\mathrm{P}<0.001$ or $* * \mathrm{P}<0.01$ using analysis of variance and Student-Neuman-Keuls test. (C) One million R-SI NTS cells were injected into the right mice flanks, and one million R-SI NTSR1 cells were injected into the left mice flanks of the same mouse $(n=18)$. In a second set, one million LNM-R cells were injected only into the right mice flanks $(\mathrm{n}=36)$. (D) Tumor growth generated by mixture of cells expressing or not NTS One million LNM35 or a 50/50 mixture of R-SI NTS and LNM-R cells or a 50/50 mixture of LNM-R and LNM-F or a 50/50 mixture of R-SI NTS and LNM-F cells were injected in the right mice flanks, 28, 17, 11 and 14 mice were injected, respectively. For A, C and D Tumor volumes were measured every week. The ellipsoid formula $(4 / 3 \mathrm{PI} \times(\mathrm{L} / 2 \times 1 / 2 \times \mathrm{h} / 2))$ was used to calculate the volume. Significant differences are shown at $* * * \mathrm{P}<0.001$ and $* * \mathrm{p}<0.01$ using analysis of variance and Student-Neuman-Keuls test.

of treatment was $960.87 \pm 146.19 \mathrm{~mm}^{3}$ for the control, $367.18 \pm 53.55 \mathrm{~mm}^{3}$ for erlotinib $(\mathrm{P}=0.0008$ vs control $)$, and $612.41+104.97 \mathrm{~mm}^{3}$ for metformin treated animals $(\mathrm{P}=0.05$ vs control), respectively. Used in co-treatment, metformin did not improve the response to erlotinib. The final volume was $318.23 \pm 31.56 \mathrm{~mm}^{3}$ (Fig $6 \mathrm{~B}$ ). The tumor doubling time was in agreement with the tumor volume, with $2.87 \pm 0.13$ days, $3.09 \pm 0.07$ days, $3.85 \pm$ 0.24 days, and $4.03 \pm 0.28$ days for the control, metformin, erlotinib and metformin + erlotinib treated animals, respectively. The absence of a response of R-SI NTSR1 tumors to erlotinib or metformin, as shown in figure $6 \mathrm{C}$, is consistent with the presence of a NTS autocrine loop, leading to the sustained activation of EGFR and responsible for cancer cell aggressiveness. To confirm the absence of an effect of erlotinib and/or metformin on R-SI NTSR1 tumors, another experiment were performed when the tumors reached the larger size of approximately $150 \mathrm{~mm}^{3}$. The tumors void of NTSR 1 expression had no detectable response NTSR1 to metformin or erlotinib (Fig 6 D).

\section{Overexpression of NTSR1 in lung adenocarcinomas correlates with pejorative prognosis}

A preliminary work of our team, suggested that the NTSR1 expression is a negative prognostic marker in a selected population of stage I lung adenocarcinoma treated by surgery alone [31]. We aimed therefore at assessing 

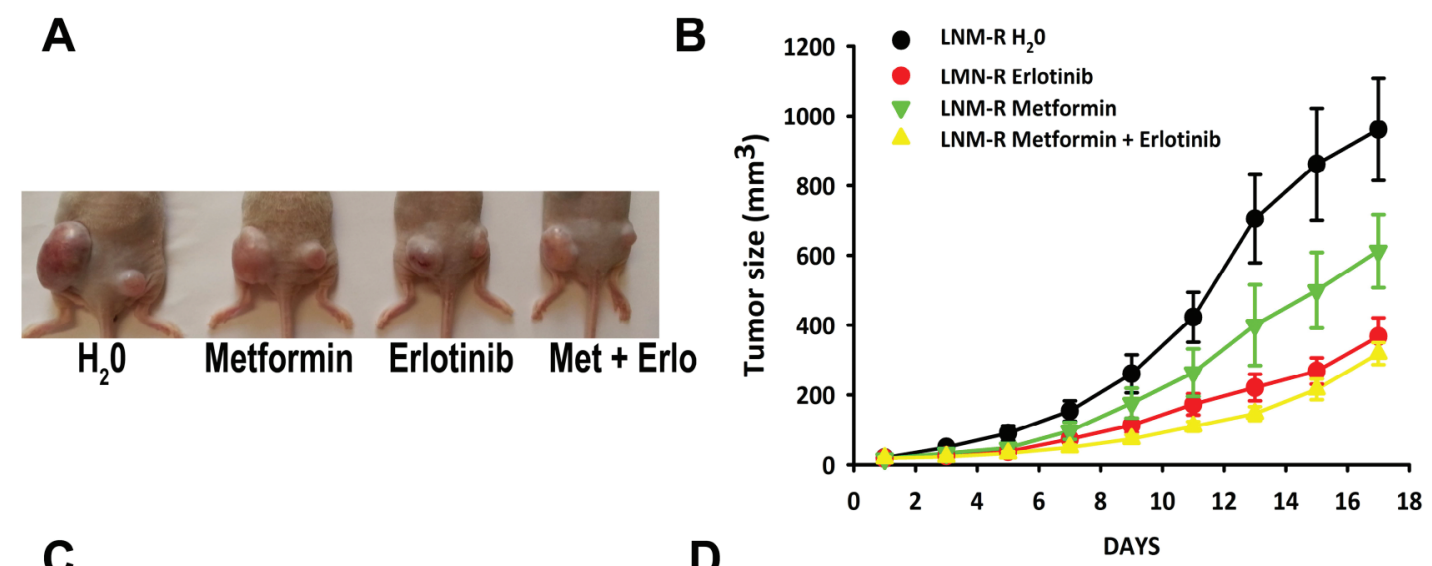

C

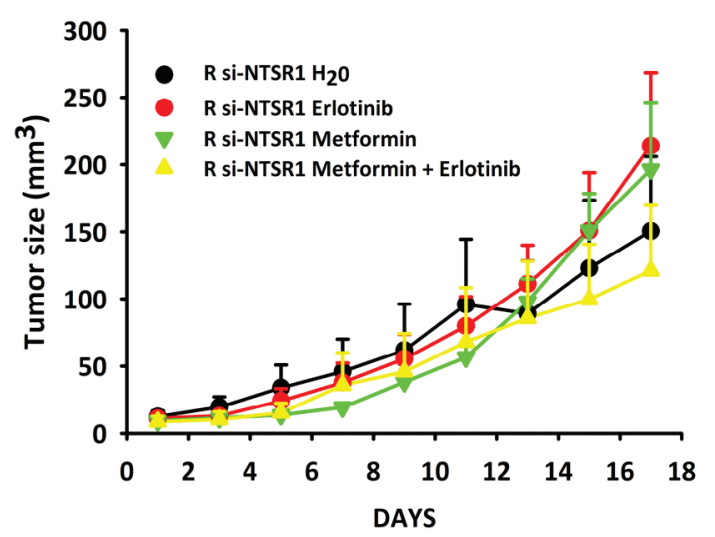

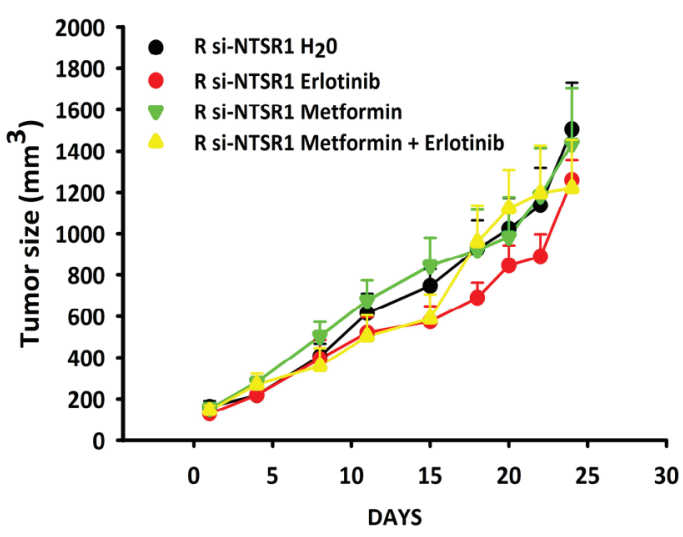

Figure 6: NTS/NTSR1 expressing tumors are the target for EGFR inhibitors treatment. (A) LNM-R or R-SI NTSR1 cells (LNM-R expressing sh-RNA for NTSR1) were injected into the left and the right flank of the mice, respectively. Here is shown an example of a mouse from each group after 17 days of treatment. (B and C) Tumor growth generated by LNM-R cells (left flank) and R-SI NTSR1 cells (right flank) xenografted into nude mice and treated for 17 days with water, or $25 \mathrm{mg} / \mathrm{kg}$ erlotinib, or $200 \mathrm{mg} / \mathrm{kg}$ metformin, or both. At day one, 9 mice per group were randomized on LNM-R tumors size reaching approximately $20 \mathrm{~mm}^{3}$. (D) Tumor growth generated by R-SI NTSR1 cells xenografted into nude mice and treated for 24 days with water, or $25 \mathrm{mg} / \mathrm{kg}$ erlotinib, or $200 \mathrm{mg} / \mathrm{kg}$ metformin, or both. At day one, 10 mice per group were randomized on tumors size reaching approximately at $150 \mathrm{~mm}^{3}$.

the prognostic significance of expression of NTSR1 in a population of consecutive patients with stage I-III NSCLC (all histotypes) referred to our institution for surgery. Firstly, we studied a population of consecutive patients operated on for NSCLC (all histotypes) between June 15, 2001 and June 14, 2002. Secondly, on the basis of initial results, only adenocarcinoma patients operated on between June 15, 2001 and December 31, 2005 were analyzed.

In the first subpopulation $(n=271$; characteristics are described in table 1), presence of NTSR1 in more than $10 \%$ of staining cells was detected in $59 \%$ of cases $(160 / 271)$, but it was never detected in normal tissues adjacent to the tumor area. In the NTSR1 semiquantitative evaluation, 111, 126, and 34 patients were scored as 0,1 and 2, respectively. In the lung adenocarcinomas, NTSR1 staining of cancer cells was granular, intracellular, heterogeneous and rarely localized at the plasma membrane (figure 7A left). On the contrary, NTSR1 staining in the squamous carcinoma cells was often localized at the membrane level (figure 7A right). Interestingly, NTSR1 positive staining was not detected in lepidic carcinomas (formerly known as bronchioloalveolar) or even in the lepidic component of invasive adenocarcinomas.

NTSR1 score 1 was detected in $48 \%$ of adenocarcinomas (57/119), $43 \%$ of squamous cell carcinomas (SCC) (46/107), and 39\% of large cell carcinomas (LCC) (14/36). NTSR1 score 2 was detected in $22 \%$ of adenocarcinomas (26/119), $7 \%$ of SCC (8/ 107), and $3 \%(1 / 36)$ of LCC. NTSR 1 score 2 was correlated with adenocarcinoma histological types $(p=0.013)$, but not with sex, age, smoking status, stage of disease and presence of vascular or lymphatic emboli. The prognostic significance of NTSR 1 expression was assessed in 228 of the 271 patients, due to postoperative deaths $(n=20)$ and loss at follow-up $(\mathrm{n}=23)$. NTSR1 score 2 was associated with poor 5-year overall survival as compared with NTSR1 scored 0 or $1(36.5 \%$ [95\% CI $22.27 \%-53.5 \%])$ 
versus 55.4\% [95\% CI 48.2\% - 62.31\%] respectively, $\mathrm{p}=0.039$ ) (Figure 7B Left). No difference was observed in survival between patients with NTSR1 score 0 and those with score 1 . Among patients with adenocarcinomas, NTSR1 score 2 was significantly associated with worse 5 -year overall survival as compared with NTSR1 score 0 or 1 (36.1\% [95\% CI 20.29\% - 55.54\%] versus $61.2 \%$ [95\% CI 50.72\% - 70.79\%], p=0.028) (Figure 7B center). In contrast, among patients with either SCC or LCC, NTSR1 score did not predict survival (Figure 7B right).

The second populations focused only on adenocarcinoma subtypes. An additional 270 consecutive patients with adenocarcinoma was added (See patient baseline characteristics in table 1). Together, a total of 389 patients with adenocarcinomas were analyzed. The NTSR1 score 2 was observed in $19.5 \%$ of patients (76/389). The correlation between NTSR1 and patient survival was determined on 363 of the 389 patients. The 5-year overall survival in this population was 55.3\%. 5-year survival was $71.3 \% ; 54.9 \%, 38.8 \%, 32.9 \%$ in patients with pT1, pT2, pT3 and pT4 tumors, respectively (p = $0.0000018)$. These figures were $65.1 \%, 50.7 \%, 34.7 \%$ for $\mathrm{pN} 0, \mathrm{pN} 1, \mathrm{pN} 2$ disease, respectively $(\mathrm{p}=0.0000001)$. The NTSR1 score 2 was associated with worse 5-year overall survival as compared with NTSR 1 score 0 and $1(42.2 \%$ $[32.42 \%-54.74 \%]$ versus $58.5 \%$ [52.62\% - 64.07\%], $\mathrm{p}=0.019)$ (Figure 7C). Multivariate analysis in all adenocarcinoma patients showed that $\mathrm{pN}(\mathrm{p}=0.0000001)$,
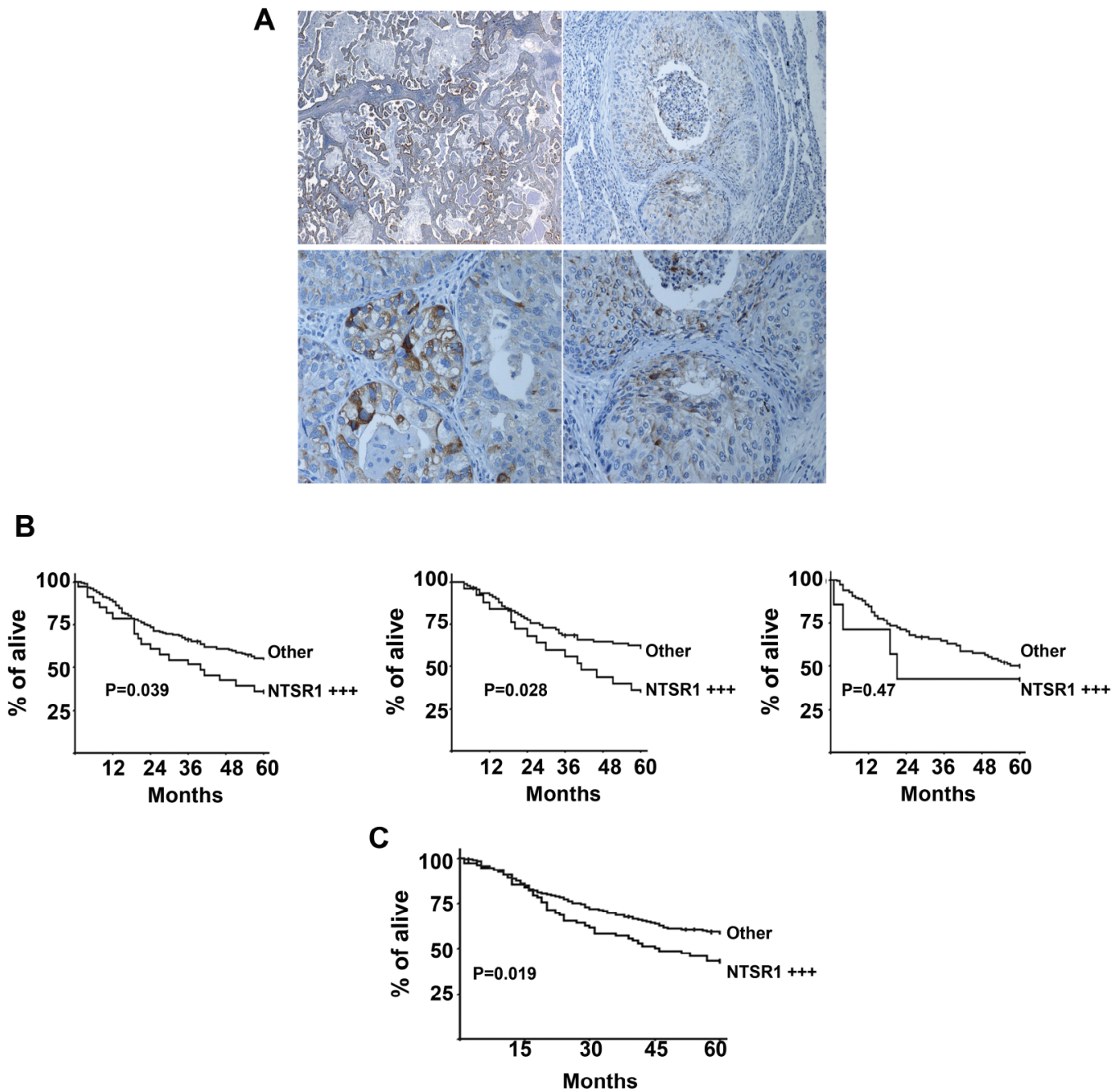

Figure 7: Immunohistochemistry of NTSR1, lung cancer tumors. (A) NTSR1 Immunolabeling in patients with primary lung adenocarcinomas (right) top X 50, bottom X400) and Squamous Cell carcinomas (left). top X100, bottom X200. (B) Overall survival of patients operated for NSCLC lung adenocarcinoma according to NTSR1 score. Semiquantitative immunohistochemistry evaluation of NTSR1: NTSR $1+++$ : strongly positive expression (number of staining cells $>50 \%$ and the labeling intensity is high $=$ score 2 ), other: the remaining patients (score 0 and 1). left Survival curve for the first cohort, Center Survival curve for lung adenocarcinomas from the first cohort, right Survival curve for SCC and LCC from the first cohort (C) Overall survival of patients operated for lung adenocarcinoma according to NTSR1 score. Semiquantitative immunohistochemistry evaluation of NTSR1: NTSR1 + + +: strongly positive expression (number of staining cells $>50 \%$ and the labeling intensity is high $=$ score 2 ), other: the remaining patients (score 0 and 1 ). 
Table 1: Clinical characteristics of patients

\begin{tabular}{|c|c|c|c|}
\hline & First cohort & Second cohort & all adenocarcinomas \\
\hline & $n^{\circ} 271(\%)$ & $n^{\circ} 270(\%)$ & $n^{\circ} 389(\%)$ \\
\hline Age mean-SD & $61.97-(10,57)$ & $60.77-(11,01)$ & $60.17(10,84)$ \\
\hline \multicolumn{4}{|l|}{ Sex } \\
\hline men & $228(75.97)$ & $183(67.78)$ & $272(69.92)$ \\
\hline women & $43(24.03)$ & $87(32.22)$ & $117(30.03)$ \\
\hline \multicolumn{4}{|l|}{\begin{tabular}{|l|} 
Tobacco history \\
\end{tabular}} \\
\hline Former smoker (stop $>2$ month) & 152 & 110 & 163 \\
\hline Current smoker & 101 & 72 & 124 \\
\hline Never smoker & 16 & 37 & 52 \\
\hline Unknown & 3 & 51 & 50 \\
\hline \multicolumn{4}{|l|}{ Resection type } \\
\hline Lobectomy/bilobectomy & $208(77)$ & $249(92.16)$ & $355(91.3)$ \\
\hline Pneumonectomy & $63(23)$ & $21(7.84)$ & $34(8.7)$ \\
\hline \multicolumn{4}{|l|}{ Stage } \\
\hline I & $115(42.5)$ & $124(46)$ & $182(46.8)$ \\
\hline II & $70(25.8)$ & $46(17)$ & $74(19)$ \\
\hline III & $86(31.7)$ & $100(37)$ & $133(34.2)$ \\
\hline \multicolumn{4}{|l|}{ Histological type $(n=484)$} \\
\hline Adenocarcinoma (ADNK) & 118 & 266 & 384 \\
\hline Bronchioloalveolar & 1 & 4 & 5 \\
\hline Squamous cell carcinoma (SCC) & 107 & - & - \\
\hline Large cell carcinoma & 36 & - & - \\
\hline Mixed (ADNK+SCC) & 6 & - & - \\
\hline Other (pleomorphic carcinomas) & 3 & - & - \\
\hline $\begin{array}{l}\text { Intratumoral or peritumoral neoplasic } \\
\text { vascular emboli }\end{array}$ & $121(44.65)$ & $104(38.25)$ & $158 / 389(40.6)$ \\
\hline $\begin{array}{l}\text { Intratumoral or peritumoral neoplasic } \\
\text { lymphatic emboli }\end{array}$ & $69(25.46)$ & $101(37.41)$ & $131 / 389(33.7)$ \\
\hline Perioperative Chemotherapy $(\mathrm{n}=267)$ & $54 / 267(20.22)$ & $56 / 247(22.67)$ & $77 / 366(21.04)$ \\
\hline Perioperative Radiotherapy $(\mathrm{n}=267)$ & $9 / 267(3.37)$ & $1 / 190(7)$ & $10 / 310(3.23)$ \\
\hline Postoperative death & 20 & 10 & 12 \\
\hline Follow-up in months, mean -SD & 41.4 & 42.4 & 42.6 \\
\hline Lost at follow-up & 23 & 9 & 14 \\
\hline Death during follow-up, $\mathrm{n}$ (\% of patients) & $105 / 228(46 \%)$ & $120 / 261(46 \%)$ & $156 / 363(42.9)$ \\
\hline \multicolumn{4}{|l|}{ NTSR1 score } \\
\hline 0 & 111 & 142 & 163 \\
\hline 1 & 126 & 78 & 150 \\
\hline 2 & 34 & 50 & 76 \\
\hline
\end{tabular}

(Continued) 


\begin{tabular}{|l|l|ll|}
\hline \multicolumn{1}{l}{ First cohort } & Second cohort & all adenocarcinomas \\
\hline \multicolumn{5}{l}{$\mathbf{n}^{\circ} \mathbf{2 7 1}(\mathbf{\%})$} & $\mathbf{n}^{\circ} \mathbf{2 7 0}(\mathbf{\%})$ & $\mathbf{n}^{\circ} \mathbf{3 8 9}(\mathbf{\%})$ \\
\hline NTSR1 & $160(59)$ & $128(47)$ & $226(58)$ \\
\hline positive & $111(41)$ & $142(52)$ & $163(42)$ \\
\hline negative &
\end{tabular}

pT $(p=0.00004)$ and NTSR1 score $2(p=0.0069)$ were independent predictors of worse survival.

\section{DISCUSSION}

Genetic defaults carried by tumors, represent specific biological markers which reveal altered regulatory pathways. The most well-known examples include the fusion genes (BCR-ABL and EML4-ALK), the activating mutations (EGFR, K-RAS, Scr, BRAF), and genomic amplification (HER2, MET). Accordingly, specific therapies employing EGFR and HER2 inhibitors or antibodies have been developed and were shown to improve the outcome of the disease. In parallel, cell signaling networks evolve with the accumulation of genetic and epigenetic alterations in connection with the local stroma and the immune system. Identification of contributing factors for tumor cell aggressiveness should enable to modulate tumor and disease progression.

Here we report that the NTS/NTSR1 complex contributed to tumor aggressiveness when it is abnormally over-expressed in tumors. The sustained activation of the NTS/NTSR1 complex generated cellular modifications resulting in the overexpression and continued stimulation of epidermal growth factor receptors. A similar result was detected using breast cancer cells. When injected into nude mice, we observed an increase in tumor growth and metastasis emergence from cells expressing NTS and NTSR1 as compared to cells expressing NTSR1 alone. The breast cells and the experimental tumors expressing NTS also displayed an increase in EGFR, HER2, and HER3 expression and activation. The latter effect was correlated with an increase of Hb-EGF, Neuregulin 2, and MMP9 [55].

Our experimental studies have shown that the NTS oncogenic action is boosted with a sustained NTSR1 state of activation. In human tumors, both NTS and NTSR 1 are expressed in $40 \%, 60 \%, 65 \%$, and $80 \%$ of breast and lung cancers, mesotheliomas, and head and neck squamous cell carcinomas, respectively, suggesting that autocrine and/or paracrine NTS regulation occurs in tumors $[32,45,46]$. Sustained activation of NTSR1 induced the overexpression of the two receptors HER2, and HER3, as well as an autocrine activation of EGFR, HER2 and HER3. The transcriptional level of these three receptors was not altered by NTS, suggesting that a new equilibrium in the sequence synthesis-activation- degradation-recycling is therefore taking place in the cells under the influence of NTS. The higher expression of the HER2 isoform suggests that a larger proportion of dimers containing HER2 should be activated in the cell. This context was previously described in breast cancer cells with HER2 gene amplification. It was shown that the excess of HER2 intracellular domains impaired EGFR/HER2 endocytosis [47], by preventing the entry of activated EGFR into clathrin-coated vesicles and limiting the action of phosphatases and maintaining EGFR signaling [48]. In addition, it was also reported that under HER2 overexpression, the rate of lysosomal targeting was significantly reduced, and a rapid recycling of activated EGFR back to the cell surface occurred, as well decreased ligand dissociation from the EGFR [49]. The necessary threshold of HER2 expression levels to trigger these processes is not known.

Interestingly, we show in this report that NTS chronically activates the release of HB-EGF concomitantly with neuregulin 1. Consequently, both EGFR and HER3 autocrine activities are boosted and the tumoral aggressiveness is potentiated. The contribution of MMPs and EGF "like" ligands to carcinogenesis and cancer progression is well known. Therapeutical strategies targeting these factors have been largely attempted. However, these factors are also important for many pathway of the human metabolism, as well as and major physiological functions, such as healing, angiogenesis, and gonadogenesis [50], leading to toxic effects when antagonized. One approach is to specifically antagonize their effects in cancer cells and to target an upstream regulatory factor. In this context, the NTS/NTSR1 complex would appear to be convenient, because it is specifically over-expressed in tumors and its inhibition should only impair the function of these factors where they are deleterious. The validity of this concept was tested with the use of a specific NTSR1 antagonist, SR 48692, which significantly reduced all of the NTS induced oncogenic effects $[18,51]$. The use of new pharmacological molecules to antagonize or neutralize intense and constant NTS-NTSR1 activation should reduce tumor aggressiveness as tumoral cells bearing NTS and NTSR1 are susceptible to induce sustained activation of EGFR and HER3 concomitantly, as shown in figure 2E.

The LMN-R cells did not carry activating mutations in the tyrosine kinase (TK) domain of the EGFR gene that confers sensitivity to EGFR TKIs. The sustained activation 
of EGFR caused by a NTS/NTSR1 autocrine loop, mimics the effects seen by activating EGFR mutations. As expected, the tumors expressing the NTS/NTRS1 complex are responsive to erlotinib, an EGFR inhibitor given to patients with lung cancer bearing EGFR mutations [10]. In contrast, tumors void of NTSR 1 expression and borne by the same mice were not responsive to erlotinib. No additional responses were seen with the concomitant treatment of metformin and erlotinib, confirming the hypothesis that the signaling events are in the same cascade.

We previously found that NTSR 1 expression is associated with adenocarcinomas prognosis. This result was confirmed by multivariate analysis, which showed that among the available clinical and pathologic factors, the NTSR1 score 2, T, and N were independent predictors of worse prognosis. High expression of NTSR1 has been found to be associated to poor survival also in other cancers. Dupouy et al found that NTSR1 expression involving $\geq 80 \%$ tumor cells was associated with worse survival in breast cancer [51]. Similarly, in head and neck cancers, patients with high NTS and NTSR1 expression had a higher rate of distant metastasis [46]. Therefore, the prognostic role of the NTS system is probably correlated with its activation rate. In this context, the difference in staining between the different histological subtypes in our series explains the respective prognostic role of NTSR1. Within adenocarcinomas, NTSR1 staining was never detected in bronchioloalveolar subtypes or in the bronchioloalveolar component of mixed adenocarcinoma but it was often detected in its invasive compartment, suggesting a role favoring tumor invasion and migration. In SCC the staining was found primarily at the membrane as in the non-stimulated cells and was non associated with survival. In vitro studies have shown that NTS is capable of modulating the migratory ability of adherent cancer cells of different origins (colon, ductal pancreatic, head and neck squamous cell, breast). In addition, it has been showed that NTSR1 induces and enhances the invasive phenotype in prostate cancer cells ( $\mathrm{LNCaP}$ ) and HNSCC tumor cells. Involved mechanisms remain unclear but metalloproteinase are probably involved [46,52].

The NTS/NTSR 1 complex could be used as a marker to identify subsets of human cancers, and thus make eligible new drugs, kinase inhibitors, or immunotherapy, targeting HERs protein or their downstream pathways. The clinical criteria used to propose these therapies are based on the detection of genetic defaults in the tumor (HER2 amplification, EGFR mutation). Nevertheless, it was also observed that other patient subsets could benefit from these therapies. The challenge is find a criteria to categorize them. For example, cells with neuregulin 1 high expression in association with HER3 autocrine activation and without HER2 amplification, are good responders to lapatinib or HER2 kinase inhibitors [53].

\section{CONCLUSION}

Our findings implicate the NTS/NTSR1 complex as a contributor to cancer aggressiveness by enhancing concomitantly the expression and activation of three receptors EGFR, HER2, HER3. Presently, only EGFR mutated tumors are eligible to receive EGFR TKI, representing $10 \%$ of all lung cancer patients [54]. From our findings, we propose that patients bearing this complex should be responders to kinase inhibitors, and that inhibition of NTS/NTSR1 complex should reduce the rate of tumor progression, providing a longer therapeutic window for the practitioners to treat their patients. Accordingly, our results indicate that an additional 20\% of patient might benefit for these therapy.

\section{MATERIALS AND METHODS}

\section{Cell culture procedures}

The LNM35 cell line was sub-cloned by limiting dilution, after few days of culture, clones containing exclusively flat or rounded cells were saved and were named LNM-F for Flat, LNM-R for Rounded. All cells were grown at $37{ }^{\circ} \mathrm{C}$, in a humidified atmosphere of $5 \% \mathrm{CO}_{2}$.

\section{Cell proliferation assays}

20000 cells/well of lung cancer cells were seeded in 24-well culture plates. Medium was replaced by FCS-free medium in presence or absence of NTS or JMV449 $10^{-8} \mathrm{M}$. Cells were counted after 5 days of treatment with a particle count and size analyzer (Z1 Coulter Particle Counter, Beckman Coulter). For LNM-F/LNM-R (20/80 \%) cell mixture: Cells were seeded in 48-well culture plates at a concentration of 40000 cells/well, media containing $10 \%$ FCS. Media is changed 24h after for a media containing $0.1 \%$ FCS cells are counted after 48 hours.

\section{Western blots}

$2 \times 10^{6}$ cells were grown for $72 \mathrm{~h}$ then serumstarved for $48 \mathrm{~h}$ in a phenol red-free medium in presence or absence of different concentrations of $5 \times 10^{-6} \mathrm{M} \mathrm{SR}$ 48692 and $25 \times 10^{-9} \mathrm{M}$ MMP inhibitor (Calbiochem), and lysed $(20 \mathrm{mM}$ Tris $\mathrm{pH} 8.0,150 \mathrm{mM} \mathrm{NaCl}, 5 \mathrm{mM}$ $\mathrm{MgCl} 2,0,5 \% \mathrm{NP} 40,0.5 \%$ glycerol, $1 \mathrm{mM}$ PMSF, protease and phosphatase inhibitor cocktail) at $4{ }^{\circ} \mathrm{C}$ for $30 \mathrm{~min}$. Primary antibodies were incubated overnight at $4^{\circ} \mathrm{C}$ according to the manufacturer's instructions. Total anti-EGFR (1:500), anti-phospho-EGFR (1:500), anti-phospho-HER2 (1:500), anti-HER3 (1:2000), antiphospho-HER3 (1:1000) were from Cell Signaling Technology. Total anti-HER2 (1:2000) was purchased 


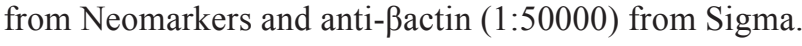
Secondary anti-rabbit (Santa Cruz Biotechnology) or anti-mouse (Sigma) antibodies, conjugated to HRP, were used at 1:2000 dilutions for $1 \mathrm{~h}$ at room temperature and visualised by enhanced chemiluminescence (GE Healthcare).

\section{Immunofluorescence assays}

Cells were seeded on $12 \mathrm{~mm}$-diameter glass slides for 24 hours, fixed in $5 \%$ paraformaldehyde for 1 hour at room temperature, permeabilized in PBS $/ 0.5 \%$ Triton $\mathrm{X}-100$ for $30 \mathrm{~min}$ and saturated for $20 \mathrm{~min}$ in PBS+ $(1: 100(\mathrm{~m} / \mathrm{v}) \mathrm{BSA}, 1: 250(\mathrm{v} / \mathrm{v})$ cold fish skin gelatin in PBS 1X, pH 8.0). Cells were then incubated overnight at $4{ }^{\circ} \mathrm{C}$ with the primary antibody diluted to $1: 100$ in PBS $0.1 \%$ Triton X-100. NTS immunoreactivity was detected using a rabbit polyclonal anti-NTS immunoglobulin (NA1230, Tebu-Bio) and NTSR1 with a goat polyclonal antibody directed against the human $\mathrm{COOH}$ terminus of the receptor (C20, Santa Cruz Biotechnology). Slides were incubated for 1 hour with a fluorescent secondary antibody (1:100) : a cyanin 3 anti-rabbit immunoglobulin or a FITC-coupled anti-rabbit or goat immunoglobulin (Jackson ImmunoResearch). Nuclei were counterstained for 5 min with DAPI 1:50000.

\section{Tumor xenografts}

Lung cancer cell xenografts were initiated in nude mice by subcutaneous injection of $10^{6}$ cells of LNM35, LNM-F, LNM-R, or derivative cell clones. For tumors generated from a cell mixture, $10^{6}$ cells from each clone were plated together 72 hours prior to injection. Four to six series were performed; each series included 5-8 mice. All procedures were in accordance with the "Guide of the Care and Use of laboratory Animals".

For drug treatments, $10^{6}$ of LNM-R or R-SI NTSR1 cells (LNM-R expressing sh-RNA for NTSR1) were injected into nude mice by subcutaneous injection, R-SI NTSR1 cells in the right flank and LNM-R cells in the left flank. 7 days after injection, 4 groups of 9 mice were randomized on the size of LNM-R as follows: $19.79 \pm$ $3.00 \mathrm{~mm}^{3}$ for control group, $18.66 \pm 2.21 \mathrm{~mm}^{3}$ for erlotinib group, $16.82 \pm 3.32 \mathrm{~mm}^{3}$ for metformin group and 18.82 $\pm 3.00 \mathrm{~mm}^{3}$ for metformin and elotinib group. Mice were treated for 17 days per os, with water, or $25 \mathrm{mg}$ / $\mathrm{kg}$ erlotinib, or $200 \mathrm{mg} / \mathrm{kg}$ metformin or both. A second experiment was performed 15 days after injection of R-SI NTSR1 cells. Four groups of 10 mice were randomized as follows: $161.37 \pm 29.13 \mathrm{~mm}^{3}$ for control group, 129.19 $\pm 20.89 \mathrm{~mm}^{3}$ for erlotinib group, $152.76 \pm 27.86 \mathrm{~mm}^{3}$ for metformin group and $145.30 \pm 23.4 \mathrm{~mm}^{3}$ for metformin and erlotinib group. Mice were treated for 24 days per os, with water, or $25 \mathrm{mg} / \mathrm{kg}$ erlotinib, or $200 \mathrm{mg} / \mathrm{kg}$ metformin, or both.

\section{Patients and tissue specimens for NTSR1 immunohistochemistry}

A two-step procedure was followed. Firstly, we studied a population of consecutive patients operated on for NSCLC (all histotypes, including adenocarcinoma) in the Thoracic Surgery Dpt of the Hôtel-Dieu Hospital, Paris, France between June 15, 2001 and June 14, 2002. Secondly, on the basis of initial results, only adenocarcinoma patients operated on between June 15, 2001 and December 31, 2005 were analyzed. Patient characteristics, treatment procedures, and short-term and long-term outcomes were retrospectively collected using a standardized case report form. Furthermore, a centralized pathological blind revision of the samples was performed by two expert pathologists (D.D., A.L.). In this revision, histologic subtype was determined on the basis of the new International Association for the Study of Lung Cancer/American Thoracic Society/ European Respiratory Society classification.

Adjuvant radiotherapy or chemotherapy was performed under the care of referring physicians, so no uniform protocol was employed. Long-term outcome was assessed by direct telephone interviews with patient or family (in case of deceased patients). When no clinical follow-up was available, information on vital status was obtained through the municipality of birth of the patient. Informed consent was obtained from all patients. The research was conducted according to recommendations outlined in the Helsinki declaration. Institutional Review Board approval was obtained (CPP Ile de France II, 2012).

\section{Immunohistochemistry}

Procedure is detailed in SI. For all cases histologic slides of primary tumors were obtained from paraffin wax embedded tissues. Standard H\&E staining was used to ensure the tumoral character of the specimen. Deparaffinized tissue sections $(4 \mu \mathrm{m})$ were incubated at $4^{\circ} \mathrm{C}$ overnight with primary antibody included anti-NTS (1:200, SC-20806, Santa Cruz biotechnology $\left.{ }^{\circledR}\right)$, antiNTSR1 (1:100; C-20, Santa Cruz Biotechnology $\left.{ }^{\circledR}\right)$ and anti-ErbB3 (1:50, NCL-c-erbB-3, Novocastra $\left.{ }^{\mathrm{TM}}\right)$, and anti-ErbB2 (1:400, A0485, Dako) was incubated at room temperature for 30 minutes.

For prognosis evaluation, all specimens were scored by an anatomopathologist with special interest in pulmonary pathology (DD). NTSR1 staining of cancer cells was scored as positive in the presence of staining cells $>10 \%$. Semi-quantitative evaluation was also performed: 0 : no staining; 2 : more than $50 \%$ of tumor cell showing a positive stain of high intensity; 1: intermediate cases.

\section{Statistical analysis}

Statistical analysis was carried out using test student T test or Student-Newman-Keuls Multiple Comparisons 
Test : *** $\mathrm{P}<0.001, * * \mathrm{P}<0.01$, and $* \mathrm{P}<0.05$. For human studies, data processing and analysis were performed with the statistical software system SEM (SILEX Development, Mireffleurs, France). Correlations were carried out by the Spearman rank correlation or H-test, as appropriate. Survival analysis was carried out by the Kaplan-Meier method, and univariate comparisons of curves were performed using log rank tests. Risk factors associated with outcomes in univariate analysis with a $\mathrm{p}$ value $<0.05$ were entered into a multivariate Cox model analysis, to identify independent predictors of survival. A $p$ value of less than 0.05 was considered significant.

\section{GRANT SUPPORTS AND ACKNOWLEDGEMENTS}

This work has been supported by INSERM, ANR-10-INTB-1503 NTS-Polyplex and CARDIF grants; SD was supported by the "Ligue contre le cancer". MY was recipient of Syrian government fellowship. We thank Dr Neil Insdorf for his kind help in editing the manuscript. We thank Dr Gregoire Prevost for providing BIM 46174. We thank Sylvie Dumont, Patricia Bonjour and Beatrice Marmey for their excellent assistance with the immunohistochemistry. We thank Dr Helene Blons for checking for EGFR mutations.

The authors declare that they have no competing interests

SD, MY, ZW, Carried out the experiments

AML Carried out genetic experiments

$\mathrm{NM}$, analyzed the mouse tissues

TT provide the LNM 35 cell line

JT, JFF participated in the design of the clinical part of the study

DD provided and analyzed the human tissues and participated in the design of the clinical part of the study

MA,PF conceived of the study

All the authors meet the authorship requirements, and have read and approved the manuscript.

\section{Additional Methods}

In order to confirm that both cell types were from the same origin, microsatellite analysis was performed using D17S250 and D17S513, which showed identical patterns for LNM-R, LNM-F and LNM35 (data not shown).

\section{RT-PCR and quantitative PCR}

$1 \mu \mathrm{g}$ of total RNA was subjected to reverse transcription, during 1 hour at $37{ }^{\circ} \mathrm{C}$, using $1 \mu \mathrm{g}$ of nonspecific hexameric random primers $\mathrm{dN}, 1 \mathrm{mM} \mathrm{dNTP}$, $10 \mathrm{mM}$ dithiothreitol, 24 units RNaseOUT and 200 units of M-MLV-RT enzyme (Invitrogen). The PCR amplification was performed on 1:10 $(\mathrm{v} / \mathrm{v})$ of the 1:10-diluted reverse transcription reaction using $0.2 \mathrm{mM}$ dNTP, $2.5 \mathrm{mM} \mathrm{MgCl}_{2}$ and 1 unit of Thermostart Taq DNA polymerase (Thermo Scientific), and $25 \mathrm{pmol}$ of each specific primer :

NTS (5'-CAGCTCCTGGAGTCTGTGCT-3' and 5'-GAGTATGTAGGGCCTTCTGGG-3')

NTSR1 (-5'-CGTGGAGCTGTACAACTTCA-3 , and 5'-CAGCCAGCAGACCACAAAGG-3)

HER3 (5'-ATGGGGAACCTTGAGATTGTGCT-3' and 5'-ACAGCTTCTGCCATTGTCCT-3')

EGFR

(5'-TTTCGATACCCAGGACCAAGCCACAGCAGC-3' and 5' AATATTCTTGCTGGATGCGTTTCTGTA-3') HER2 (5'-GTGCTAGACAATGGAGACC-3' and 5'-CACAAAATCGTGTCCTGGTAGC-3') 18S (5'-AGGAATTGACGGAAGGGCAC-3' and 5'-GTGCAGCCCCGGACATCTAAG-3') 36B4 (5'-GTGCAGCCCCGGACATCTAAG-3' and 5'-GATTGGCTACCCAACTGTTG-3')

Semi-quantitative amplification was performed in a DNA thermal cycler 9700 (Perkin Elmer Applied Biosystem), and Maxima SYBRGreen qPCR Master Mix (Fermentas) in a Mx3000P qPCR system (Stratagene) was used for quantitative PCR.

\section{NTS Radioimmunoassay (RIA)}

RIA was performed on culture media from one million cells were grown in $60 \mathrm{~mm}^{2}$ Petri dishes for 24, 48, or 72 hours. RIA was performed as previously described Scarceriaux V et al Endocrinology 1995;136:2554-60, and detailed in Alifano M et al Clin Cancer Res 2010;16:4401-10.

\section{Flow cytometry}

The assessment of the G1 and S phases of cell cycle on LNM-R, LNM-F and LNM-F/LNM-R mixtures were conducted using IP tests. 40000 cells were seeded in 48-wells culture plates in complete medium. After 24 hours, medium was replaced by $0.1 \%$ FCS-counting medium. The cells were pelleted, $500 \mu \mathrm{L}$ of $1 \mathrm{nM}$ IP was added to solubilize the pellet and incubated at $37^{\circ} \mathrm{C}$ during $10 \mathrm{~min}$.

\section{Immunohistochemistry}

Deparaffinized TMA sections $(4 \mu \mathrm{m})$ were subjected to heat-induced epitope retrieval in citrate buffer ( $\mathrm{pH}$ 6.0). The sections were labeled for the target proteins using the avidin-biotin-peroxidase complex method. The slides were incubated at $4^{\circ} \mathrm{C}$ overnight with primary antibody included anti-NTS (1:200, SC-20806, Santa Cruz biotechnology $\left.{ }^{\circledR}\right)$ and anti-ErbB3 (1:50, NCL-c-erbB-3, Novocastra ${ }^{\mathrm{TM}}$ ), anti-NTSR1 (1:100; C20, Santa CruzBiotechnology $\left.{ }^{\circledR}\right)$ and anti-ErbB2 (1:400, A0485, Dako) were incubated at room temperature for 1 hour and 30 minutes respectively. These slides were then incubated with appropriate biotinylated secondary antibodies, NTS (Trekkie Biotinylates rabbit link, Biocare medical ${ }^{\circledR}$ ), NTSR1 (Biotinylated anti-goat IgG, 
Vector laboratories, Inc), ErbB3 (Trekkie Biotinylates mouse link, Biocare medical $\left.{ }^{\circledR}\right)$. The antigen-antibody complex was revealed with avidin-biotinperoxidase complex, according to the manufacturer's instructions, NTSR1 (Vectastain ABC Kit, Vector laboratories, Inc.), NTS and ErbB3 (Trekavidin- HPR label, Biocare medical $\left.{ }^{\circledR}\right)$. ErbB2 was biotinylated and revealed with the NovoLink ${ }^{\mathrm{TM}}$ Polymer Detection System (Leica $\left.{ }^{\circledR}\right)$. NTSR1 and ErbB2 staining were done with diaminobenzidine tetrahydrochlorid, NTS and ErbB3 were done with aminoethyl carbazole. All slides were counterstained with hematoxylin.

For prognosis evaluation, NTSR1 immunoreactivity was detected using a specific antibody against the carboxy terminus of NTSR1 (1:100; C-20, Santa Cruz Biotechnology). These sections were then incubated with biotinylated secondary antibody (1:100; Vector laboratories, Inc). The antigen-antibody complex was revealed with avidin-biotinperoxidase complex, according to the manufacturer's instructions for the Vectastain ABC Kit (Vector laboratories, Inc.). Staining was done with diamino-benzidine tetrahydrochlorid. All slides were counterstained with hematoxylin.

\section{REFERENCES}

1. Siegel R, Naishadham D and Jemal A. Cancer statistics, 2013. CA Cancer J.Clin. 2013; 63(1):11-30.

2. Jemal A, Bray F, Center MM, Ferlay J, Ward E and Forman D. Global cancer statistics. CA Cancer J.C lin. 2011; 61(2):69-90.

3. Goldstraw P, Crowley J, Chansky K, Giroux DJ, Groome PA, Rami-Porta R, Postmus PE, Rusch V and Sobin L. The IASLC Lung Cancer Staging Project: proposals for the revision of the TNM stage groupings in the forthcoming (seventh) edition of the TNM Classification of malignant tumours. J.Thorac.Oncol. 2007; 2(8):706-714.

4. Mountain CF. Revisions in the International System for Staging Lung Cancer. Chest. 1997; 111(6):1710-1717.

5. Mountain CF and Dresler CM. Regional lymph node classification for lung cancer staging. Chest. 1997; 111(6):1718-1723.

6. Giaccone G. Epidermal growth factor receptor inhibitors in the treatment of non-small-cell lung cancer. J.Clin. Oncol. 2005; 23(14):3235-3242.

7. Hirsch FR, Janne PA, Eberhardt WE, Cappuzzo F, Thatche r N, Pirker R, Choy H, Kim ES, Paz-Ares L, Gandara DR, Wu YL, Ahn MJ, Mitsudomi T, Shepherd FA and Mok TS. Epidermal growth factor receptor inhibition in lung cancer: status 2012. J.Thorac.Oncol. 2013; 8(3):373-384.

8. Hanahan D and Weinberg RA. Hallmarks of cancer: the next generation. Cell. 2011; 144(5):646-674.

9. Lynch TJ, Bell DW, Sordella R, Gurubhagavatula S, Okimoto RA, Brannigan BW, Harris PL, Haserlat SM,
Supko JG, Haluska FG, Louis DN, Christiani DC, Settleman J and Haber DA. Activating mutations in the epidermal growth factor receptor underlying responsiveness of non-small-cell lung cancer to gefitinib. N.Engl.J.Med. 2004; 350(21):2129-2139.

10. Pao W, Miller V, Zakowski M, Doherty J, Politi K, Sarkaria I, Singh B, Heelan R, Rusch V, Fulton L, Mardis E, Kupfer D, Wilson R, Kris M and Varmus H. EGF receptor gene mutations are common in lung cancers from "never smokers" and are associated with sensitivity of tumors to gefitinib and erlotinib. Proc.Natl.Acad.Sci.U.S.A. 2004; 101(36):13306-13311.

11. Garcia de Palazzo IE, Adams GP, Sundareshan P, Won g AJ, Testa JR, Bigner DD and Weiner LM. Expression of mutated epidermal growth factor receptor by nonsmall cell lung carcinomas. Cancer Res. 1993; 53(14): 3217-3220.

12. Citri A and Yarden Y. EGF-ERBB signalling: towards the systems level. Nat.Rev.Mol.Cell Biol. 2006; 7(7):505-516.

13. Hynes NE and MacDonald G. ErbB receptors and signaling pathways in cancer. Curr.Opin.Cell Biol. 2009; 21(2): 177-184.

14. Carraway $\mathrm{R}$ and Leeman SE. The isolation of a new hypotensive peptide, neurotensin, from bovine hypothalami. J.Biol.Chem. 1973; 248(19):6854-6861.

15. Reinecke M. Neurotensin. Immunohistochemical localization in central and peripheral nervous system and in endocrine cells and its functional role as neurotransmitter and endocrine hormone. Prog.Histochem.Cytochem. 1985; 16(1):1-172.

16. Rosell S, Thor K, Rokaeus A, Nyquist O, Lewenhaupt A, Kager L and Folkers K. Plasma concentration of neurotensin-like immunoreactivity (NTLI) and lower esophageal sphincter (LES) pressure in man following infusion of (Gln4)-neurotensin. Acta Physiol Scand. 1980; 109(4):369-375.

17. Vincent JP, Mazella J and Kitabgi P. Neurotensin and neurotensin receptors. Trends Pharmacol.Sci. 1999; 20(7):302-309.

18. Wu Z, Martinez-Fong D, Tredaniel $\mathrm{J}$ and Forgez $\mathrm{P}$. Neurotensin and its high affinity receptor 1 as a potential pharmacological target in cancer therapy. Front Endocrinol. (Lausanne). 2012; 3(184).

19. Thomas RP, Hellmich MR, Townsend CM Jr and Evers BM. Role of gastrointestinal hormones in the proliferation of normal and neoplastic tissues. Endocr. Rev. 2003; 24(5):571-599.

20. Muller KM, Tveteraas IH, Aasrum M, Odegard J, Dawood M, Dajani O, Christoffersen T and Sandnes DL. Role of protein kinase $\mathrm{C}$ and epidermal growth factor receptor signalling in growth stimulation by neurotensin in colon carcinoma cells. BMC.Cancer. 2011; 11(421).

21. Ehlers RA, Zhang Y, Hellmich MR and Evers BM. Neuro tensin-mediated activation of MAPK pathways and AP-1 
binding in the human pancreatic cancer cell line, MIA PaCa2. Biochem.Biophys.Res.Commun. 2000; 269(3):704-708.

22. Seufferlein T and Rozengurt E. Galanin, neurotensin, and phorbol esters rapidly stimulate activation of mitogenactivated protein kinase in small cell lung cancer cells. Cancer Res. 1996; 56(24):5758-5764.

23. Zhao D, Kuhnt-Moore S, Zeng H, Wu JS, Moyer MP and Pothoulakis C. Neurotensin stimulates IL-8 expression in human colonic epithelial cells through Rho GTPasemediated NF-kappa B pathways. Am.J.Physiol Cell Physi ol. 2003; 284(6):C1397-C1404.

24. Lee LF, Guan J, Qiu Y and Kung HJ. Neuropep tide-induced androgen independence in prostate cancer cells: roles of nonreceptor tyrosine kinases Etk/Bmx, Src, and focal adhesion kinase. Mol.Cell Biol. 2001; 21(24):8385-8397.

25. Leyton J, Garcia-Marin L, Jensen RT and Moody TW. Neurotensin causes tyrosine phosphorylation of focal adhesion kinase in lung cancer cells. Eur.J.Pharmacol. 2002; 442(3):179-186.

26. Guha S, Lunn JA, Santiskulvong C and Rozengurt E. Neu rotensin stimulates protein kinase $\mathrm{C}$-dependent mitogenic signaling in human pancreatic carcinoma cell line PANC1. Cancer Res. 2003; 63(10):2379-2387.

27. Hassan S, Dobner PR and Carraway RE. Involveme nt of MAP-kinase, PI3-kinase and EGF-receptor in the stimulatory effect of Neurotensin on DNA synthesis in PC3 cells. Regul.Pept. 2004; 120(1-3):155-166.

28. Moody TW, Chiles J, Casibang M, Moody E, Chan D and Davis TP. SR48692 is a neurotensin receptor antagonist which inhibits the growth of small cell lung cancer cells. Peptides. 2001; 22(1):109-115.

29. Maoret JJ, Anini Y, Rouyer-Fessard C, Gully D and Laburthe M. Neurotensin and a non-peptide neurotensin receptor antagonist control human colon cancer cell growth in cell culture and in cells xenografted into nude mice. Int.J.Cancer. 1999; 80(3):448-454.

30. Souaze F, Viardot-Foucault V, Roullet N, Toy-MiouLeong M, Gompel A, Bruyneel E, Comperat E, Faux MC, Mareel M, Rostene W, Flejou JF, Gespach C and Forgez P. Neurotensin receptor 1 gene activation by the Tcf/ beta-catenin pathway is an early event in human colonic adenomas. Carcinogenesis. 2006; 27(4):708-716.

31. Alifano M, Souaze F, Dupouy S, Camilleri-Broet S, Younes M, hmed-Zaid SM, Takahashi T, Cancellieri A, Damiani S, Boaron M, Broet P, Miller LD, Gespach C, Re gnard JF and Forgez P. Neurotensin receptor 1 determines the outcome of non-small cell lung cancer. Clin.Cancer Res. 2010; 16(17):4401-4410.

32. Dupouy S, Viardot-Foucault V, Alifano M, Souaze F, Plu-Bureau, Chaouat M, Lavaur A, Hugol D, Gespach C, Gompel A and Forgez P. The neurotensin receptor-1 pathway contributes to human ductal breast cancer progression. PLoS.One. 2009; 4(1):e4223.
33. Souaze F, Dupouy S, Viardot-Foucault V, Bruyneel E, Attoub S, Gespach C, Gompel A and Forgez P. Expression of neurotensin and NT1 receptor in human breast cancer: a potential role in tumor progression. Cancer Res. 2006; 66(12):6243-6249.

34. Najimi M, Souaze F, Mendez M, Hermans E, Berbar T, Rostene $\mathrm{W}$ and Forgez P. Activation of receptor gene transcription is required to maintain cell sensitization after agonist exposure. Study on neurotensin receptor. J.Biol. Chem. 1998; 273(34):21634-21641.

35. Souaze F. Maintaining cell sensitivity to G-protein coupled receptor agonists: neurotensin and the role of receptor gene activation. J.Neuroendocrinol. 2001; 13(5):473-479.

36. Toy-Miou-Leong M, Cortes CL, Beaudet A, Rostene $\mathrm{W}$ and Forgez P. Receptor trafficking via the perinuclear recycling compartment accompanied by cell division is necessary for permanent neurotensin cell sensitization and leads to chronic mitogen-activated protein kinase activation. J.Biol. Chem. 2004; 279(13):12636-12646.

37. Kozaki K, Miyaishi O, Tsukamoto T, Tatematsu Y, Hida $\mathrm{T}$, Takahashi $\mathrm{T}$ and Takahashi $\mathrm{T}$. Establishment and characterization of a human lung cancer cell line NCIH460-LNM35 with consistent lymphogenous metastasis via both subcutaneous and orthotopic propagation. Cancer Res. 2000; 60(9):2535-2540.

38. Prevost GP, Lonchampt MO, Holbeck S, Attoub S, Zaharevitz D, Alley M, Wright J, Brezak MC, Coulomb H, Savola A, Huchet M, Chaumeron S, Nguyen QD, Forgez P, Bruyneel E, Bracke M, Ferrandis E, Roubert P, Demarquay D, Gespach C and Kasprzyk PG. Anticancer activity of BIM-46174, a new inhibitor of the heterotrimeric Galpha/Gbetagamma protein complex. Cancer Res. 2006; 66(18):9227-9234.

39. Gully D, Canton M, Boigegrain R, Jeanjean F, Molimard JC, Poncelet M, Gueudet C, Heaulme M, Leyris R and Brouard A. Biochemical and pharmacological profile of a potent and selective nonpeptide antagonist of the neurotensin receptor. Proc.Natl.Acad.Sci.U.S.A. 1993; 90(1):65-69.

40. Kettunen E, Anttila S, Seppanen JK, Karjalainen A, Edgre n H, Lindstrom I, Salovaara R, Nissen AM, Salo J, Mattso n K, Hollmen J, Knuutila S and Wikman H. Differentially expressed genes in nonsmall cell lung cancer: expression profiling of cancer-related genes in squamous cell lung cancer. Cancer Genet.Cytogenet. 2004; 149(2):98-106.

41. Ettinger DS, Akerley W, Borghaei H, Chang AC, Cheney RT, Chirieac LR, D'Amico TA, Demmy TL, Govindan R, Grannis FW Jr, Grant SC, Horn L, Jahan TM, Komaki R, Kong FM, Kris MG, Krug LM, Lackner RP, Lennes IT, Loo BW Jr, Martins R, Otterson GA, Patel JD, Pinder-Schenck MC, Pisters KM, Reckamp K, Riely GJ, Rohren E, Shapiro TA, Swanson SJ, Tauer K, Wood DE, Yang SC, Gregory K and Hughes M. Non-small cell lung cancer, version 2.2013. J.Natl.Compr.Canc.Netw. 2013; 11(6):645-653. 
42. Mei ZB, Zhang ZJ, Liu CY, Liu Y, Cui A, Liang ZL, Wang $\mathrm{GH}$ and Cui L. Survival benefits of metformin for colorectal cancer patients with diabetes: a systematic review and metaanalysis. PLoS.ONE. 2014; 9(3):e91818.

43. Kisfalvi K, Eibl G, Sinnett-Smith J and Rozengurt E. Metformin disrupts crosstalk between $\mathrm{G}$ protein-coupled receptor and insulin receptor signaling systems and inhibits pancreatic cancer growth. Cancer Res. 2009; 69(16):6539-6545.

44. Soares HP, Ni Y, Kisfalvi K, Sinnett-Smith J and Rozengurt E. Different patterns of Akt and ERK feedback activation in response to rapamycin, active-site mTOR inhibitors and metformin in pancreatic cancer cells. PLoS.One. 2013; 8(2):e57289.

45. Alifano M, Loi M, Camilleri-Broet S, Dupouy S, Regnard JF and Forgez P. Neurotensin expression and outcome of malignant pleural mesothelioma. Biochim ie. 2010 ; 92(2):164-170.

46. Shimizu S, Tsukada J, Sugimoto T, Kikkawa N, Sasaki K, Chazono H, Hanazawa T, Okamoto Y and Seki N. Identification of a novel therapeutic target for head and neck squamous cell carcinomas: a role for the neurotensinneurotensin receptor 1 oncogenic signaling pathway. Int.J.Cancer. 2008; 123(8):1816-1823.

47. Wang Z, Zhang L, Yeung TK and Chen X. Endocytos is deficiency of epidermal growth factor (EGF) receptorErbB2 heterodimers in response to EGF stimulation. Mol. Biol.Cell. 1999; 10(5):1621-1636.

48. Offterdinger $\mathrm{M}$ and Bastiaens PI. Prolonged EGFR signaling by ERBB2-mediated sequestration at the plasma membrane. Traffic. 2008; 9(1):147-155.
49. Worthylake R, Opresko LK and Wiley HS. ErbB-2 amplification inhibits down-regulation and induces constitutive activation of both ErbB-2 and epidermal growth factor receptors. J.Biol.Chem. 1999; 274(13):8865-8874.

50. Falls DL. Neuregulins: functions, forms, and signaling strategies. Exp.Cell Res. 2003; 284(1):14-30.

51. Dupouy S, Mourra N, Doan VK, Gompel A, Alifano M and Forgez P. The potential use of the neurotensin high affinity receptor 1 as a biomarker for cancer progression and as a component of personalized medicine in selective cancers. Biochimie. 2011; 93(9):1369-1378.

52. Vias M, Burtt G, Culig Z, Veerakumarasivam A, Neal DE and Mills IG. A role for neurotensin in bicalutamide resistant prostate cancer cells. Prostate. 2007; 67(2): 190-202.

53. Wilson TR, Lee DY, Berry L, Shames DS and Settleman J. Neuregulin-1-mediated autocrine signaling underlies sensitivity to HER2 kinase inhibitors in a subset of human cancers. Cancer Cell. 2011; 20(2):158-172.

54. Lee JK, Hahn S, Kim DW, Suh KJ, Keam B, Kim TM, Lee $\mathrm{SH}$ and Heo DS. Epidermal growth factor receptor tyrosine kinase inhibitors vs conventional chemotherapy in non-small cell lung cancer harboring wild-type epidermal growth factor receptor: a meta-analysis. JAMA. 2014; 311(14):1430-1437.

55. Dupouy S, Doan VK, Wu Z, Mourra N, Liu J, De Wever O, Llorca FP, Cayre A, Kouchkar A, Gompel A, Forgez P. Oncotarget. 2014; in press. 